\title{
Paleomagnetic study of the Messejana Plasencia dyke (Portugal and Spain): A lower Jurassic paleopole for the Iberian plate
}

\author{
A. Palencia Ortas ${ }^{a, *}$, M.L. Osete ${ }^{\mathrm{a}, 1}$, R. Vegas $^{\mathrm{b}}$, P. Silva $^{\mathrm{c}}$ \\ ${ }^{\text {a }}$ Dept. de Geofisica, Facultad de C.C. Físicas, Universidad Complutense de Madrid, Av. de la Complutense s/n, 28040 Madrid, Spain \\ ${ }^{\mathrm{b}}$ Dep. de Geodinámica, Facultad de C. Geológicas, Universidad Complutense de Madrid, Spain \\ ' ISEL/DEC, R. Conselheiro Emídio Navarro, 1, 1950-062 Lisboa, Portugal
}

Received 20 December 2005; received in revised form 21 March 2006; accepted 6 April 2006

Available online 30 May 2006

\begin{abstract}
The only Iberian lower Jurassic paleomagnetic pole come from the "Central Atlantic Magmatic Province"-related Messejana Plasencia dyke, but the age and origin of its remanence have been a matter of discussion. With the aim of solving this uncertainty, and to go further into a better understanding of its emplacement and other possible tectonic features, a systematic paleomagnetic investigation of 40 sites (625 specimens) distributed all along the $530 \mathrm{~km}$ of the Messejana Plasencia dyke has been carried out. Rock magnetic experiments indicate PSD low Ti-titanomagnetite and magnetite as the minerals carrying the NRM. The samples were mostly thermally demagnetized. Most sites exhibit a characteristic remanent component of normal polarity with the exception of two sites, where samples with reversed polarities have been observed. The paleomagnetic pole derived from a total of 35 valid sites is representative of the whole structure of the dyke, and statistically well defined, with values of $\mathrm{PLa}=70.4^{\circ} \mathrm{N}, \mathrm{PLo}=237.6^{\circ} \mathrm{E}$, $K=47.9$ and $A_{95}=3.5^{\circ}$. Paleomagnetic data indicates that: (i) there is no evidence of a Cretaceous remagnetization in the dyke, as it was suggested; (ii) most of the dyke had a brief emplacement time; furthermore, two dyke intrusion events separated in time from it by at least 10,000 y have been detected; (iii) the high grouping of the VGPs directions suggests no important tectonic perturbations of the whole structure of the dyke since its intrusion time; (iv) the pole derived from this study is a good quality lower Jurassic paleopole for the Iberian plate; and (v) the Messejana Plasencia dyke paleopole for the Iberian plate is also in agreement with quality-selected European and North American lower Jurassic paleopoles and the magnetic anomalies data sets that are available for rotate them to Iberia.
\end{abstract}

(C) 2006 Elsevier B.V. All rights reserved.

Keywords: Paleomagnetism; CAMP; Dyke; Iberia; Jurassic

\section{Introduction}

The Messejana Plasencia dolerite dyke constitutes the northeasternmost expression of the vast, more than 10 million $\mathrm{km}^{2}$, Central Atlantic Magmatic Province

\footnotetext{
* Corresponding author. Fax: +34 913944398.

E-mail address: ali@fis.ucm.es (A. Palencia Ortas).

${ }^{1}$ Fax: +34 913944398 .
}

(CAMP) that is present in four continents: southwestern Europe, northwestern Africa, eastern North America and northeaster South America (e.g. Marzoli et al., 1999). It corresponds to the main representation of the CAMP in Europe and is comparable to other great dykes - Caraquet and Shelburne in Canada, Foum Zguid in Morocco - characteristic of the northern Province.

The dyke forms a SW-NE, slightly-curved alignment of dolerite intrusions along a prominent topographic 
lineament, more than $500 \mathrm{~km}$ in length, that obliquely crosses the South Portuguese, Ossa Morena and Central Iberian zones of the Variscan Iberian Massif(Fig. 1). The length of the dyke must be even greater since its northern extreme disappears under the Neogene cover of the Duero Basin and the southern branch could continue under the Atlantic Ocean, to the south of the Portuguese coast.

The first published ages of the dyke were dispersed. A time of intrusion between $186 \pm 6 \mathrm{Ma}$ and $148 \pm 8 \mathrm{Ma}$ was obtained from $\mathrm{K}-\mathrm{Ar}$ whole rock methods (Schermerhorn et al., 1978), whilst an interval between 209 $\pm 6 \mathrm{Ma}$ and $137 \pm 4 \mathrm{Ma}$ was reported from mineral concentrates, generally plagioclase (Schott et al., 1981). These authors considered that the dispersion in age reflected the actual time interval of the intrusion. No conclusive ${ }^{40} \mathrm{Ar} /{ }^{39} \mathrm{Ar}$ results were obtained by Sebai et al. (1991). However, more recently published ${ }^{40} \mathrm{Ar} /{ }^{39} \mathrm{Ar}$ radiometric ages of $203 \pm 2 \mathrm{Ma}$ (Dunn et al., 1998) and $202.8 \pm 2.0 \mathrm{Ma}$ (Rapaille et al., 2003) point to a brief period of intrusion, in accordance with the other regions of the Central Atlantic Magmatic Province.

Previous paleomagnetic studies were carried out on the dyke by Schott et al. (1981) and Perrin et al. (1991). Schott et al. (1981) studied 12 sites along the dyke that were systematically alternating field (AF) demagnetized, and occasionally chemically demagnetized. Perrin et al. (1991) carried out a paleointensity study in 6 sites from the central part of the dyke. Both studies found exclusively normal polarities with a relatively high scatter in directions that was interpreted by these authors as being due to a relatively long intrusion time and to the paleosecular variation of the geomagnetic field. The authors concluded that the dyke had multiple intrusion events. The pole derived from the study of Schott et al. (1981) is the only paleomagnetic pole of early Jurassic age for the Iberian plate.

There are two consistent upper Jurassic (Oxfordian) paleomagnetic poles for Iberia, both derived from magnetostratigraphic studies (Steiner et al., 1985; Juárez et al., 1994, 1995). Juárez et al. (1994, 1995, 1996, 1998) carried out a systematic magnetostratigraphic and paleomagnetic study on 13 sites from the Iberian Ranges. In addition to a small primary component these authors observed a strong overprint interpreted as acquired in Cretaceous times (Juárez et al., 1998). Strong remagnetizations of normal polarity have also been observed in Jurassic sediments from the Lisbon area (western part of central Iberia, Galdeano et al., 1989), the southern Iberian Ranges (central Iberia, Moreau et al., 1992) and the Betics (southern Iberia, Villalaín et al., 1994, 1996). The similarity in direction of this Cretaceous remagnetized component with the Messejana Plasencia dyke direction calculated by Schott et al. (1981), along with the absence of samples with reversed polarities, were the main arguments given by Juárez et al. (1996) to doubt the primary origin of the magnetization of the dyke and to postulate the existence of an important event that remagnetized most Jurassic rocks at the Iberian plate.

Finally, an interesting geometrical feature of the Messejana Plasencia dyke is the change in its trend (Fig.

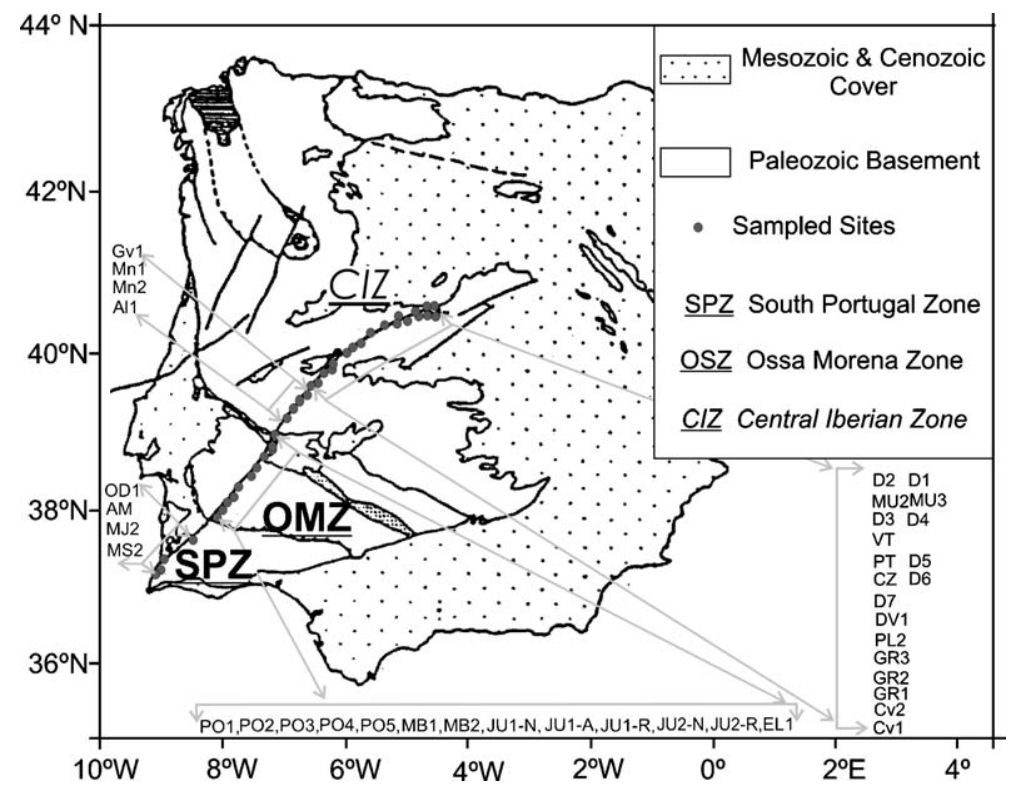

Fig. 1. Simplified geological map of the Iberian Peninsula showing the locations of the studied sites of the Messejana Plasencia dyke. 
1). There is a tectonic model trying to interpret the angular deviation present in the northern part of the Messejana Plasencia dyke located in the Spanish Central System. The Spanish Central System constitutes an important morphostructural intraplate feature of Iberia that resulted from a concentration of crustal strain derived from stresses applied on the boundaries of the Betics and Pyrenees. This compressive regime was caused by the convergence of the African and European plates and subsequent accretion of Iberia to both Europe and Africa, from the Eocene up to the Tortonian. Vegas et al. (1990) proposed a tectonic model of the Spanish Central System in which deformation of this zone was produced by a mid-late Mesozoic shear zone, which absorbed part of the Iberia-Eurasia relative motion (Fig. 2 ). The subsequent $\mathrm{N}-\mathrm{S}$ Africa-Eurasia convergence was partly accommodated within this intraplate zone weakness. The deformation within this E-W shear zone was partially compensated by means of blocks rotations and forced uplifting of the upper crust. Within this context, directions from the northern branch of the Messejana Plasencia dyke should be clockwise rotated with respect to paleomagnetic directions obtained from the southern branch.

The objectives of this new study of the Messejana Plasencia dyke are: (i) to resolve the uncertain origin of the magnetization of the dyke, ii) to obtain a new lower Jurassic paleomagnetic pole for the Iberian Peninsula (in the case of no remagnetization), (iii) to investigate if the dyke was intruded in a brief period of time or had a multiphase emplacement, (iv) to check if the angular deviation present in the northern part of the Messejana Plasencia fault and dyke is related to block rotations. In order to achieve these objectives we have carried out a new rock magnetic and a paleomagnetic study along the whole extension of the dyke.

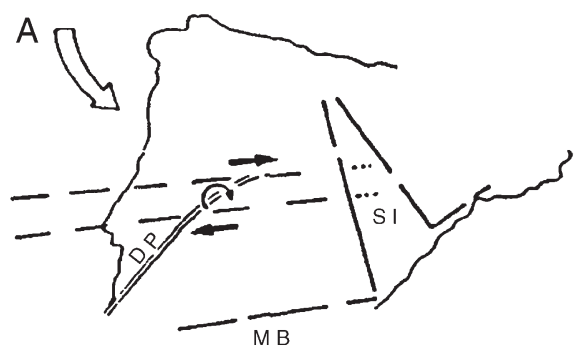

\section{Geological setting and sampling}

Historically the dyke was first mapped along $170 \mathrm{~km}$ in southern Portugal (Torre de Assunção, 1949) and then its prolongation was described along the rest of its length in Spain (Del Valle Lersundi, 1959; García de Figuerola, 1963, 1965; García de Figuerola and Carnicero, 1973). Since the early descriptions, the occurrences of the dyke have been ascribed to a fault line younger than the Variscan folding (Feio, 1951). The fault has been also recognized as left-handed strike-slip with an offset ranging from 3 to $1.5 \mathrm{~km}$ (Zbyszewski and Freire de Andrade, 1957; Quesada García, 1960; Carvalhosa, 1965; Schermerhorn et al., 1978; Rincón et al., 2000).

The age of the fault that served as channel for the intrusion is a matter of debate. First descriptions refer it to a post-Hercynian fault formation with middle to late Pliocene reactivation (Feio, 1951; Carvalhosa, 1965; Parga, 1969). Later, Schermerhorn et al. (1978), by comparison with other dolerite dykes around the Atlantic, suggested a middle Triassic origin for the fault in connection with the early rifting of the Atlantic.

The age of the fairly small left-lateral motion of the fault possess also some problems. It could be slightly younger than, or coeval with, the dolerite intrusion because the dyke occurrences follow several typical strike-slip features - sigmoidal, en échelon relays; borders of small pull-apart basins; extensional and contractional bends and steps. The small lateral component of the fault could be related to the motion along an incipient intracontinental shear zone developed between Africa and Eurasia in the early stages of the Atlantic rifting (Vegas, 2000). On the other hand, the left lateral motion could also be related to a recent, mostly Tertiary and Quaternary, reactivation of the fault,

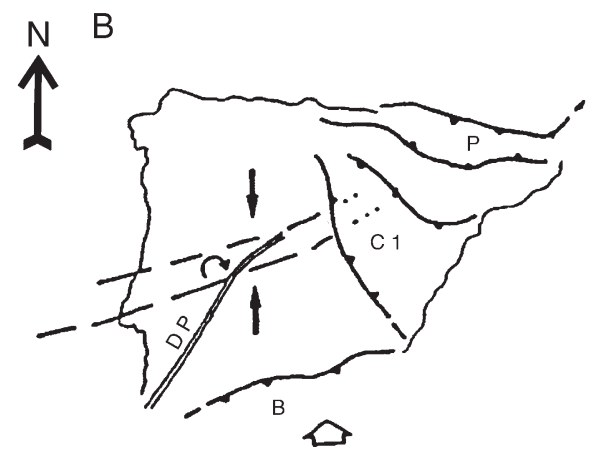

Fig. 2. Deformed zone related to the Spanish Central System proposed by Vegas et al. (1990). A) Late Cretaceous single shear zone and clockwise rotation of crustal blocks. B) Middle-late Miocene pure shear within the lower crust causing reactivation of rotations, uplift and reverse high angle faults at the boundaries. $\mathrm{B}=$ Betics; $\mathrm{CI}=$ Iberian Chain; $\mathrm{DP}=$ Plasencia Dyke; $\mathrm{MB}=$ Betic Margin; $\mathrm{P}=$ Pyrenees; $\mathrm{SI}=\mathrm{Iberian}$ Trough (modified from Vegas et al., 1990). 
A

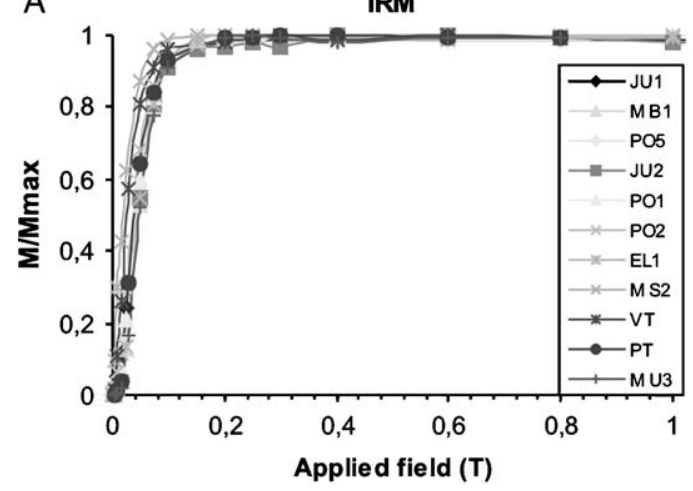

B

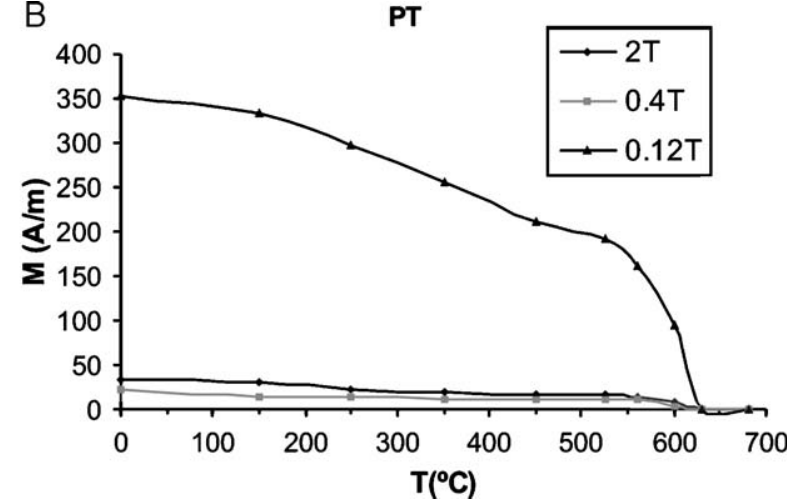

Fig. 3. A) IRM acquisition curves of samples from the dyke. B) Representative behaviour of the thermal demagnetization of a three-component IRM of a sample of the dyke (Lowrie, 1990).

considering the age of sediments included in several, small pull-apart-like basins (Capote et al., 1996; De Vicente, 2004). But surprisingly, this great tectonic lineament takes an insignificant portion of the Tertiary deformation of Iberia.

There are also different denominations of the dyke. We will refer it as Messejana Plasencia dyke combining the most current denominations for the Portuguese and Spanish segments.

The Spanish portion of the Dyke has been extensively studied, mainly from a petrological point of view, by García de Figuerola (1963, 1965), García de Figuerola and Carnicero (1973) and García de Figuerola et al. (1974). Its Portuguese part was examined by Torre de Assunção (1949, 1951a,b). Thermal histories of two host granitic rocks derived from AFT (apatite fission tracks) ages (De Bruijne, 2001) constrain the depth of intrusion of the Dyke.
The host rocks traversed the PAZ (partial annealing zone) at the time of intrusion of the Dyke (200 Ma), thereafter a depth of $2-3 \mathrm{~km}$ can be assumed for the rocks investigated.

A total of 40 sites spanning the whole of the $530 \mathrm{~km}$ Messejana Plasencia dyke have been studied (Fig. 1). Samples were cored (2.54 cm in diameter) with a portable gasoline-powered drill and oriented using an inclinometer and magnetic compass. Cores were cut in the laboratory into standard specimens $(2.2 \mathrm{~cm}$ length) for paleomagnetic measurements. Core chips and end pieces were used in some of the rock magnetic experiments.

In order to perform a contact test, the contact with the host rock was intensively investigated. Unfortunately, very often the contact did not outcrop, and when it outcropped, both the host rock and the dyke exhibited a high degree of alteration, probably related with the activity of the fault.
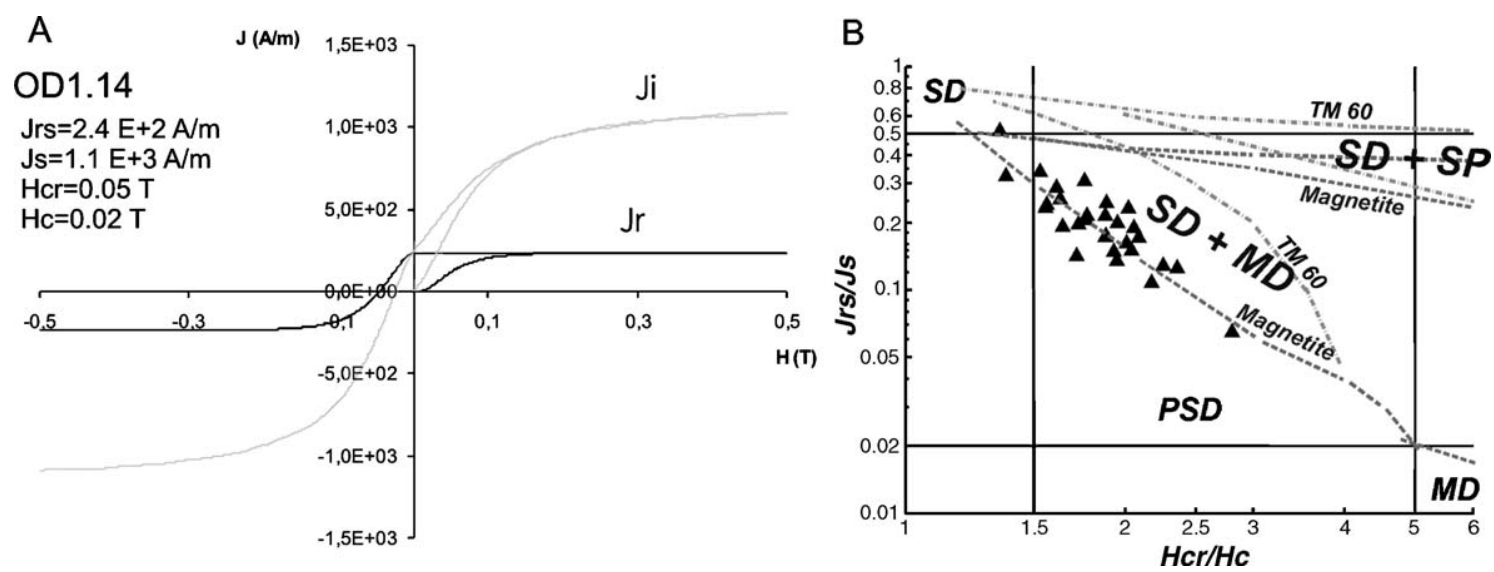

Fig. 4. A) Hysteresis curves: remanent (Jr) and induced (Ji) magnetizations of a typical sample. B) Plots of the hysteresis parameters Jrs/Js vs. Hcr/Hc of some dyke's samples (Day et al., 1977), and theoretical curves for combinations of singledomain (SD), multidomain (MD) and superparamagnetic (SP) grains for magnetite and 60\% Ti-titanomagnetite (TM60), Dunlop (2002a). 

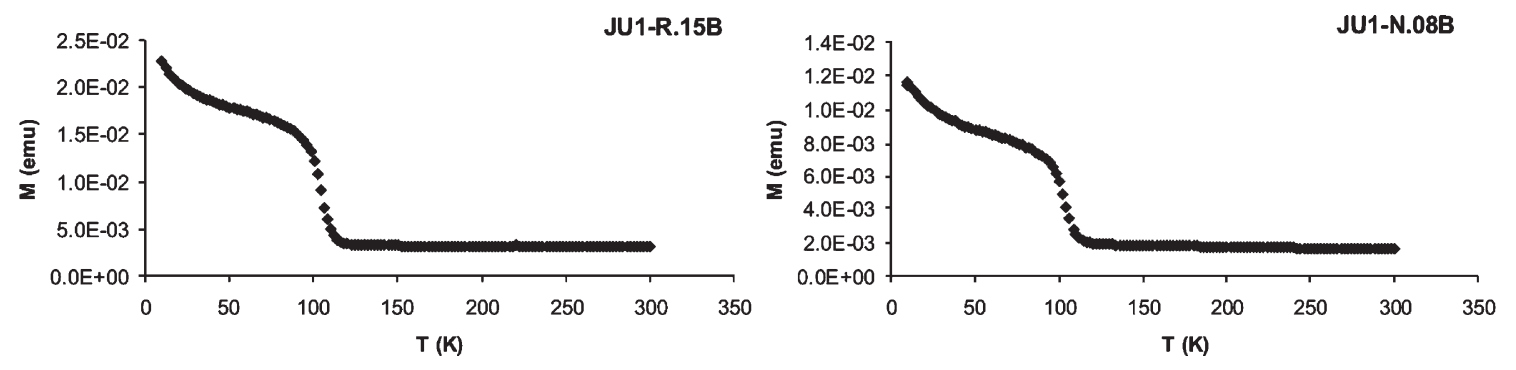

Fig. 5. Two examples of saturation remanence acquired at $4 \mathrm{~K}$ monitored during zero field heating to room temperature. JU1-R.15b corresponds to a sample which exhibited a reversed polarity and JU1-N.8b to a normal polarity.

In few localities near Juromenha (JU1 and JU2, Fig. 1) internal contacts within the main dyke were observed, which were interpreted as the intrusion of a later phase. The existence of secondary intrusions was also observed by Schermerhorn et al. (1978) in the Aljustrel area, to the south of Juromenha. In this area, we sampled 2 small secondary dykes (JU1-R and JU2-R) in addition to the main one (JU1-N and JU2$\mathrm{N})$. Due to the small dimensions of these secondary dykes, at JU2-R only 2 samples could be collected.

\section{Laboratory procedures}

The Natural Remanent Magnetization (NRM) and its response to stepwise thermal (Th) or alternating field (AF) demagnetization were measured using JR5$\mathrm{A}$ and Molspin magnetometers in the Paleomagnetic laboratory of the Complutense University in Madrid (UCM). Demagnetization was achieved using TSD-1 and GSD-5 Schonsted demagnetizers. The initial susceptibility and its variation upon thermal treatment were measured on a Kappabridge (KLY-3) instrument.

Representative samples were subjected to stepwise acquisition of uniaxial isothermal remanent magnetization (IRM) up to $1.5 \mathrm{~T}$ with a pulse magnetizer (ASC Scientific IM-10-30), with at least 16 acquisition steps.

TH demagnetization of 3-axis IRMs (Lowrie, 1990) was performed on representative specimens. The 3 orthogonal fields were $2 \mathrm{~T}, 0.4 \mathrm{~T}$ and $0.12 \mathrm{~T}$.

Hysteresis parameters were obtained for representative samples with a coercitivity spectrometer developed by the Kazan University (Burov et al., 1986). The coercivity meter measures the induced and remanent magnetization in 5E-4 T steps up to a maximum value of $0.5 \mathrm{~T}$. A sample is placed near the edge of a rotating wheel which transports the sample from the coils used to generate the applied field (the sample magnetization is measured at the same time) to a separate sensor which measures the sample remanence. For each applied field,
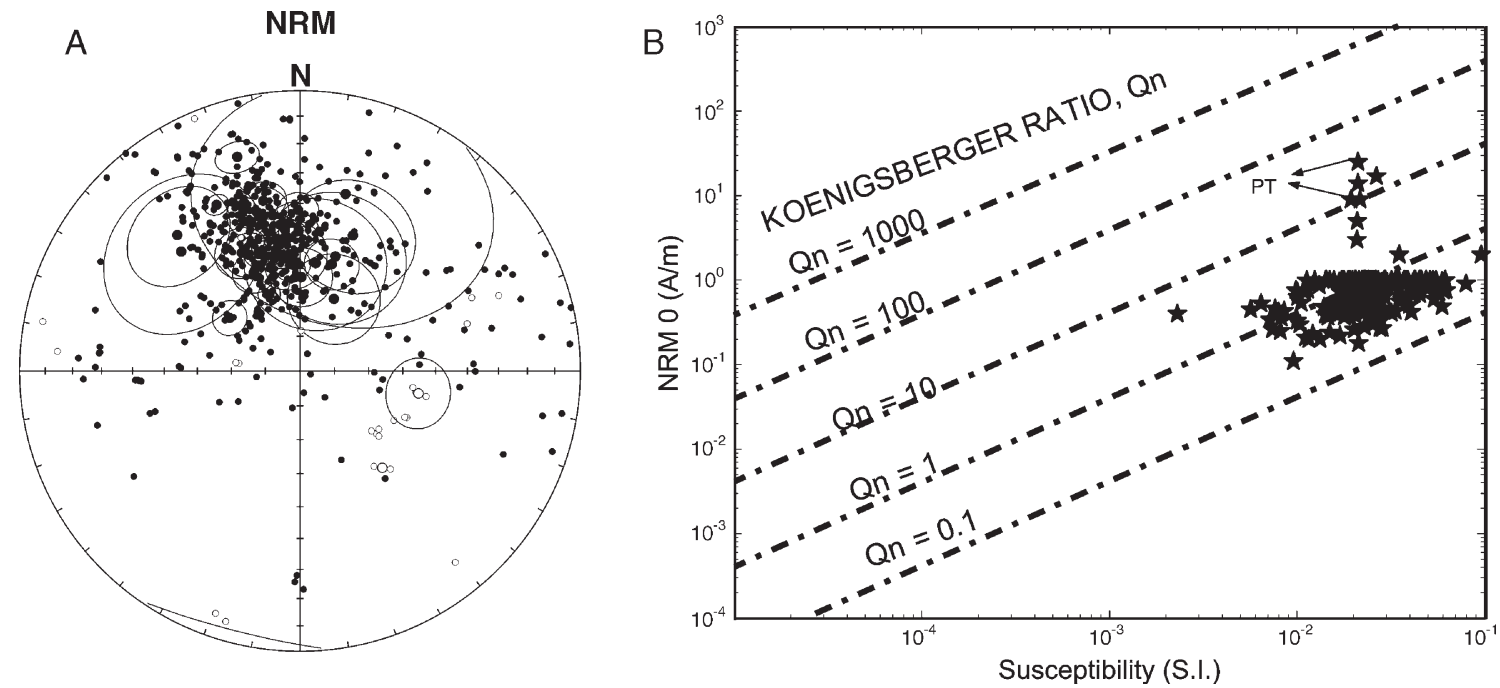

Fig. 6. A) Equal area projection of the NRM of the sampled sites, filled (open) symbols mean lower (upper) hemisphere. Mean directions and $95 \%$ confidence circle are also represented for each site. B) Initial NRM vs. initial susceptibility, Koenigsberger ratio Qn. 


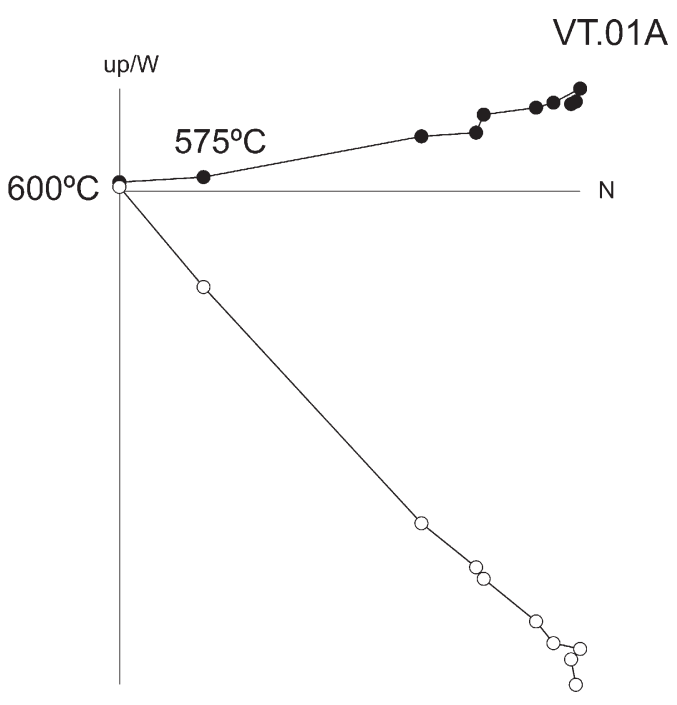

A
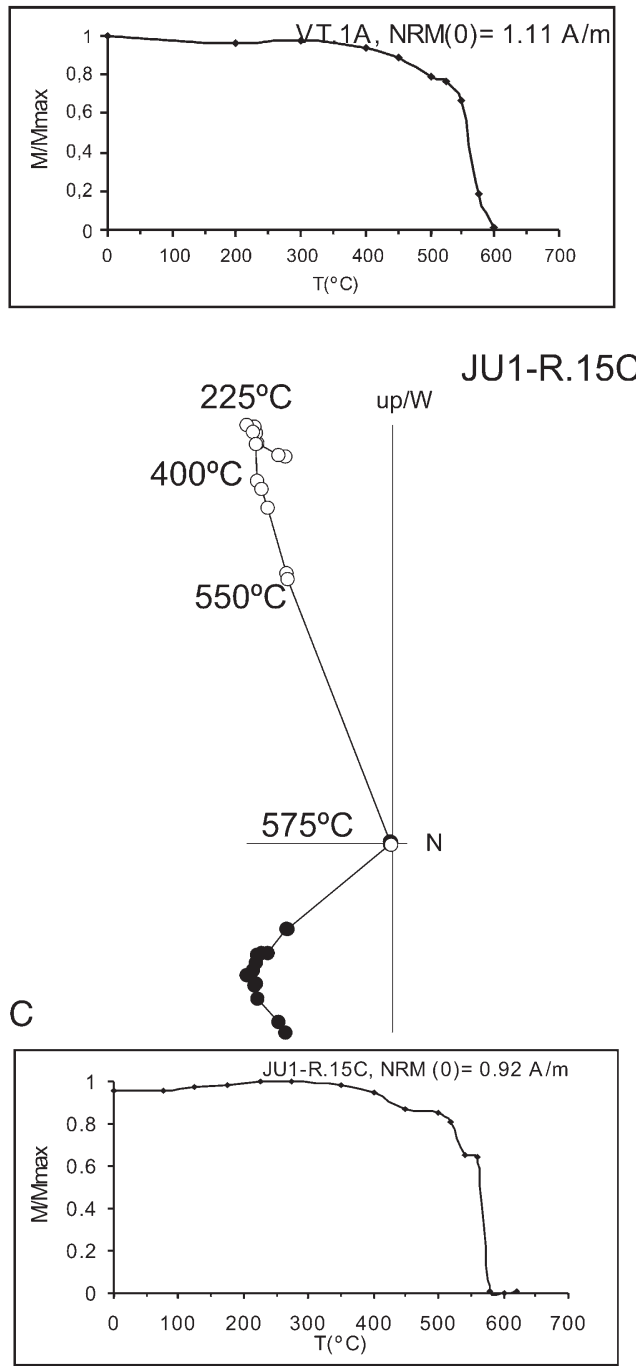
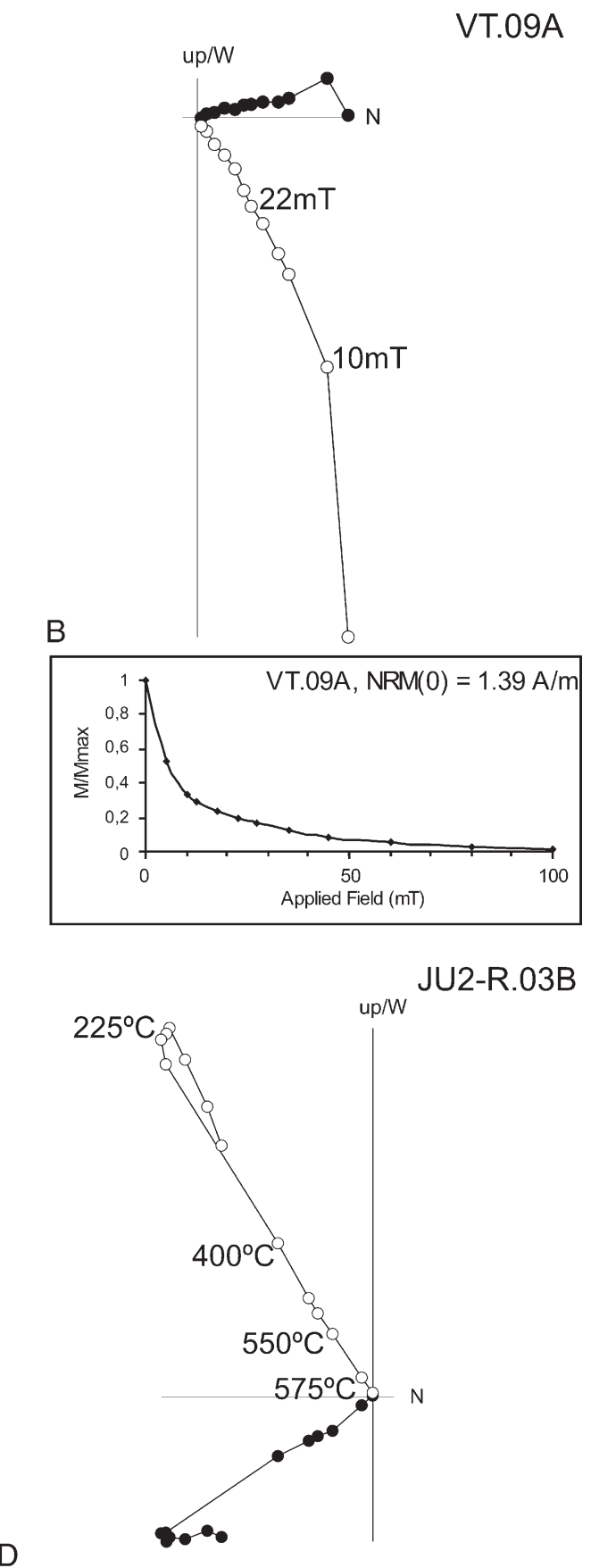

D

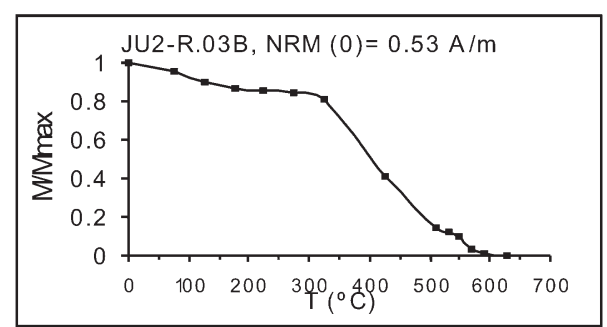



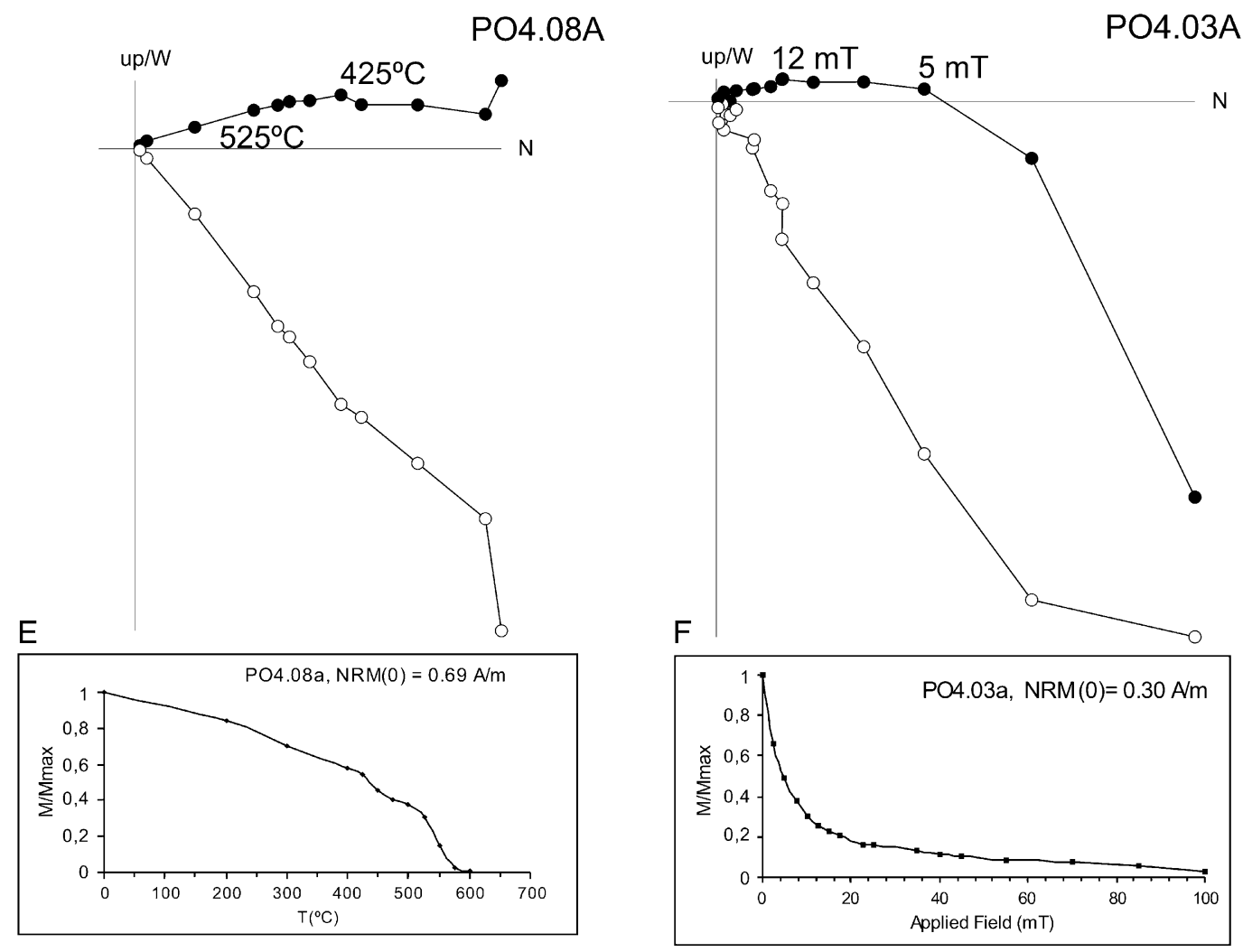

Fig. 7. Orthogonal vector plots and normalized magnetization during NRM demagnetization: A, B) Th and AF demagnetization of two typical specimens of group 1 of normal polarity; C, D) Th demagnetization of two typical samples of group 1 of reversed polarity; E, F) Th and AF demagnetization of two typical samples of group 2.

two data are measured - induced and remanent magnetization. The applied field is cycled from 0 to $+0.5 \mathrm{~T}$ then back to $-0.5 \mathrm{~T}$.

Low temperature IRM experiments were performed. Samples were cooled to $4 \mathrm{~K}$ and subjected to $5 \mathrm{~T}$ field. The remanent magnetization was monitored during zero field heating to room temperature in a MPMS-XL squid magnetometer (Quantum Design) in the CAI (X Ray diffractions) of the UCM.

\section{Rock magnetic results}

\subsection{IRM acquisition curves and thermal demagnetization of $3 D-I R M$}

All studied samples display a similar behaviour during the gradual acquisition of IRM and subsequent Th demagnetization of three orthogonal IRM components. Saturation is reached below $0.3 \mathrm{~T}$, indicating low coercitivity minerals as the carrier of the magnetization (Fig. 3A). The $0.12 \mathrm{~T}$ coercitivity fraction is completely demagnetized at $600{ }^{\circ} \mathrm{C}$ (Fig. $3 \mathrm{~B}$ ), indicating that the low coercitivity mineral is magnetite and/or low Ti-titanomagnetite. The $0.4 \mathrm{~T}$ and $2 \mathrm{~T}$ fractions made little or no contribution in the acquisition curves.

\subsection{Hysteresis properties}

The ascending and descending branches of the hysteresis curves were indistinguishable at fields greater than $0.3 \mathrm{~T}$, indicating saturation of the ferromagnetic grains. Little or no paramagnetic or diamagnetic contribution could be seen at high fields. Fig. 4A shows the induced ( $\mathrm{Ji})$ and remanent $(\mathrm{Jr})$ magnetization versus the applied field of a typical sample.

Saturation magnetization (Js), saturation remanence (Jrs), coercive force $(\mathrm{Hc})$ and coercivity of remanence (Hcr) were determined. Coercivity $(\mathrm{Hcr} / \mathrm{Hc})$ and remanence $(\mathrm{Jrs} / \mathrm{Js})$ ratios were plotted in a Day diagram (Day et al., 1977), Fig. 4B. Also plotted are the theoretical curves for combinations of singledomain (SD), multidomain (MD) and superparamagnetic (SP) grains for magnetite and $60 \%$ Ti-titanomagnetite (TM60) (Dunlop, 2002a). The data fall in the upper left part of the pseudo-single-domain region (PSD) 
region of Day plot, closely following the trend for SDMD magnetite. The hysteresis properties are interpreted as being due to a mixture of SD and MD magnetite.

\subsection{Low temperature experiments}

Samples were cooled to $4 \mathrm{~K}$ and subjected to $5 \mathrm{~T}$ field. The remanent magnetization was measured stepwise during zero field heating from $4 \mathrm{~K}$ till room temperature. The Verwey transition (Verwey and Haayman, 1941) is expressed through the large drop in remanence around $110 \mathrm{~K}$, corroborating the presence of magnetite, Fig. 5.
In summary, rock magnetic experiments show that main magnetic minerals carrying the NRM of the Messejana Plasencia dyke are a mixture of SD and MD grains of nearly pure magnetite.

\section{Paleomagnetic results}

\subsection{NRM demagnetization}

Natural Remanent Magnetization (NRM) intensity ranged from $17 \mathrm{~A} / \mathrm{m}$ to $0.1 \mathrm{~A} / \mathrm{m}$. NRM directions of the 40 investigated sites were, in general, well grouped (Fig.

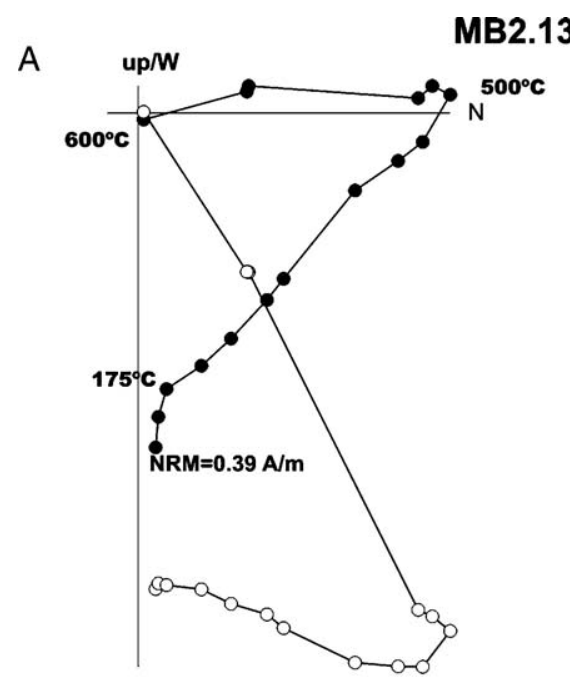

B
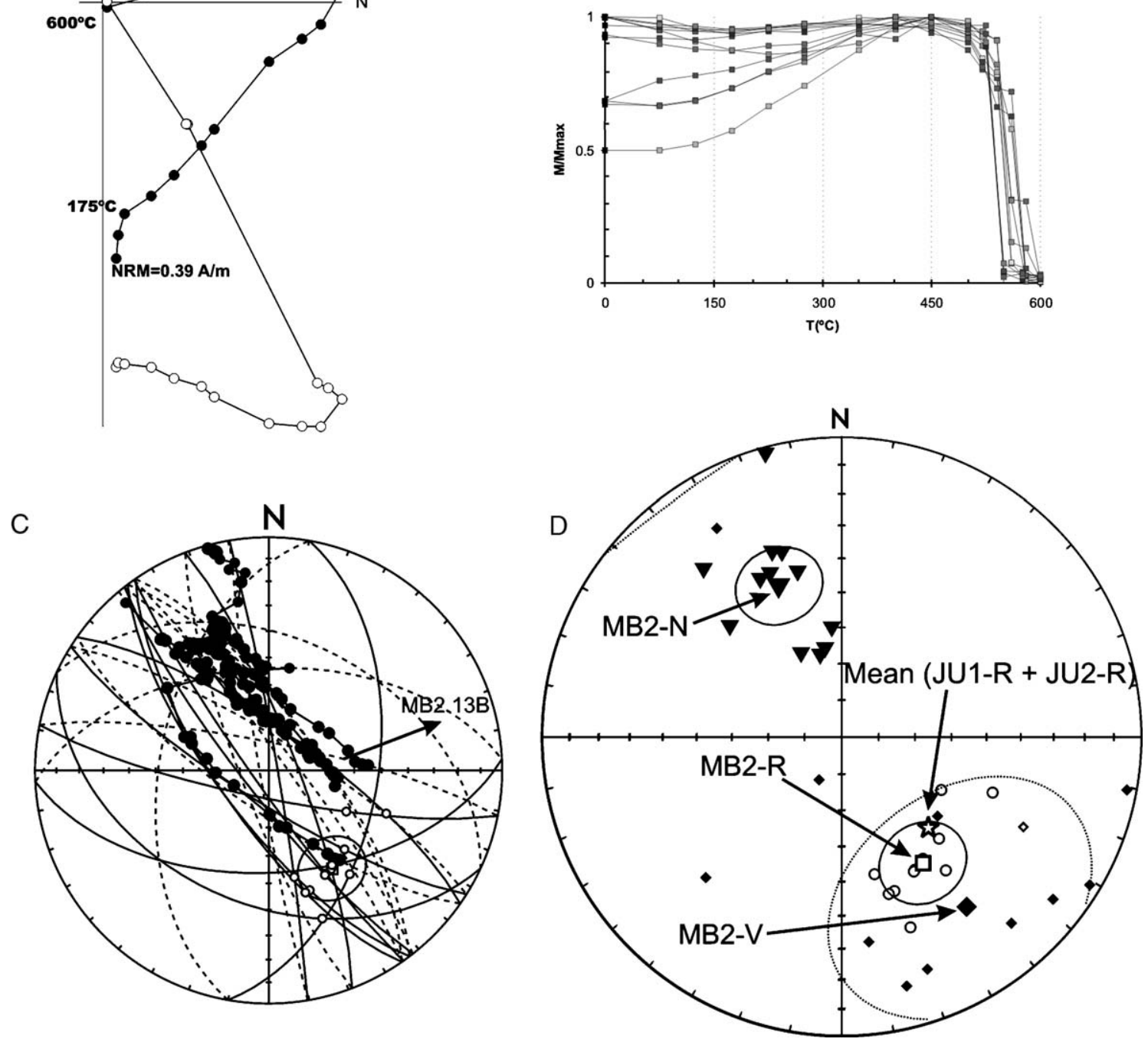

Fig. 8. A, B) Orthogonal vector plot of a typical sample of group 3 and normalized magnetization of all the specimens during NRM thermal demagnetization; C) Great circles for all the specimens during thermal demagnetization processes; D) Equal area projection of the three magnetic components of the specimens of MB2 (MB2-N, MB2-R and MB2-V), mean values with the $\alpha_{95}$ statistical parameters and mean value of the paleomagnetic reversed direction of sites JU1-R and JU2-R. 
$6 \mathrm{~A})$, with the exception of 3 sites that presented large $\alpha_{95 \%}$ values of $>20^{\circ}$. Most sites exhibited normal polarities except two (JU1-R and JU2-R) where reversed polarities were observed. In addition, site MB2, exhibited two magnetic components of normal and reversed polarities.

At JU1 and JU2 site two different outcrops were sampled: JU1-N and JU2-N correspond to the main intrusion event and gave normal polarity; JU1-R and JU2-R represent small dykes intruding into the main dyke. These narrow dykes exhibited reversed polari- ties. This indicates, at least, two different intrusion episodes.

Initial values of NRM intensities versus susceptibilities are plotted in Fig. 6B, together with the Koenigsberger ratios (Qn) (Stacey, 1967). The values obtained are consistent with a TRM origin for the NRM. At one site, PT (located in the Tornavacas pass at an altitude of $1450 \mathrm{~m}$ ) the values are more scattered: The high Qn ratios and the dispersed NRM directions suggest the presence of IRMs acquired by lightning strikes (Dunlop et al., 1984).

Table 1

Site locations; paleomagnetic directions; VGPs and statistical parameters

\begin{tabular}{|c|c|c|c|c|c|c|c|c|c|c|c|c|}
\hline Sites & SLat & SLong & $n$ & Dec & Inc & $k$ & $\alpha_{95}$ & PLa & PLo & Palat & $\mathrm{dm}$ & $\mathrm{dp}$ \\
\hline${ }^{*} M J 2$ & 37.2 & -8.9 & 10 & 357.6 & 52.6 & 32.2 & 8.6 & - & - & - & - & - \\
\hline MS2 & 37.2 & -8.9 & 11 & 342.0 & 43.1 & 167.4 & 3.5 & 70.5 & 227.9 & 25.1 & 4.3 & 2.7 \\
\hline $\mathrm{AM}$ & 37.4 & -8.9 & 15 & 2.0 & 45.6 & 42.9 & 5.9 & 79.2 & 161.5 & 27.0 & 7.5 & 4.8 \\
\hline OD1 & 37.6 & -8.6 & 11 & 346.6 & 42.1 & 189.0 & 3.3 & 72.5 & 215.9 & 24.3 & 4.1 & 2.5 \\
\hline$* * P O 1$ & 38.2 & -7.8 & 11 & 329.4 & 28.4 & 200.8 & 3.2 & 52.0 & 345.3 & 15.1 & 3.5 & 1.9 \\
\hline $\mathrm{PO} 2$ & 38.3 & -7.7 & 5 & 332.6 & 57.1 & 227.8 & 5.1 & 68.5 & 269.3 & 37.7 & 7.4 & 5.4 \\
\hline PO3 & 38.3 & -7.7 & 11 & 334.1 & 47.4 & 253.6 & 2.9 & 66.4 & 245.6 & 28.5 & 3.8 & 2.4 \\
\hline PO4 & 38.3 & -7.7 & 11 & 333.5 & 51.3 & 122.6 & 4.1 & 67.5 & 254.0 & 32.0 & 5.6 & 3.8 \\
\hline PO5 & 38.3 & -7.7 & 11 & 332.9 & 42.1 & 105.7 & 4.5 & 63.1 & 238.9 & 24.3 & 5.5 & 3.4 \\
\hline MB1 & 38.7 & -7.3 & 7 & 342.9 & 54.7 & 263.4 & 3.7 & 75.9 & 253.7 & 35.2 & 5.2 & 3.7 \\
\hline MB2-N & 38.7 & -7.3 & 12 & 337.6 & 44.3 & 16.2 & 11.1 & 67.3 & 235.3 & 26.0 & 13.9 & 8.8 \\
\hline${ }^{*} M B 2-R$ & 38.7 & -7.3 & 12 & 147.2 & -48.8 & 17.5 & 11.5 & - & - & - & - & - \\
\hline JU1-N & 38.7 & -7.3 & 8 & 348.5 & 48.2 & 77.8 & 6.3 & 76.6 & 221.2 & 29.2 & 8.2 & 5.4 \\
\hline JU1-R & 38.7 & -7.3 & 11 & 133.3 & -61.2 & 681.1 & 1.8 & 54.8 & 283.8 & 42.3 & 2.8 & 2.1 \\
\hline JU2-N & 38.7 & -7.3 & 4 & 346.5 & 47.9 & 187.0 & 6.7 & 75.2 & 225.7 & 29.0 & 8.7 & 5.7 \\
\hline JU2-R & 38.7 & -7.3 & 2 & 139.4 & -49.3 & - & - & 55.7 & 260.8 & 30.2 & - & - \\
\hline EL1 & 38.8 & -7.2 & 12 & 342.0 & 45.5 & 58.3 & 5.7 & 70.9 & 230.0 & 27.0 & 7.2 & 4.6 \\
\hline$* * A L 1$ & 39.3 & -6.8 & 8 & 279.5 & 70.5 & 22.4 & 12.0 & 36.2 & 308.2 & 54.7 & 20.8 & 18.0 \\
\hline MN2 & 39.5 & -6.8 & 10 & 335.4 & 38.2 & 18.2 & 11.6 & 62.3 & 229.8 & 21.5 & 13.7 & 8.1 \\
\hline MN1 & 39.5 & -6.8 & 8 & 343.0 & 25.7 & 73.3 & 6.5 & 60.0 & 207.9 & 13.5 & 7.0 & 3.8 \\
\hline GV1 & 39.7 & -6.6 & 12 & 339.9 & 44.3 & 264.3 & 2.7 & 68.4 & 230.3 & 26.0 & 3.4 & 2.1 \\
\hline CV1 & 39.7 & -6.5 & 11 & 339.2 & 34.0 & 362.1 & 2.4 & 62.3 & 219.9 & 18.6 & 2.7 & 1.6 \\
\hline CV2 & 39.7 & -6.5 & 5 & 331.1 & 29.9 & 11.6 & 23.4 & 55.4 & 228.5 & 16.0 & 25.9 & 14.4 \\
\hline GR1 & 39.8 & -6.3 & 11 & 345.4 & 52.1 & 95.0 & 4.7 & 76.3 & 237.1 & 32.7 & 6.4 & 4.4 \\
\hline GR2 & 39.8 & -6.3 & 7 & 355.4 & 54.7 & 114.3 & 5.7 & 84.2 & 213.7 & 35.2 & 8.1 & 5.7 \\
\hline GR3 & 39.8 & -6.3 & 8 & 343.9 & 58.4 & 54.9 & 7.5 & 77.6 & 265.7 & 39.1 & 11.1 & 8.2 \\
\hline DV1 & 39.9 & -6.2 & 12 & 349.3 & 53.1 & 28.4 & 8.3 & 79.4 & 231.0 & 33.7 & 11.5 & 8.0 \\
\hline PL2 & 40.1 & -6.1 & 8 & 318.1 & 70.0 & 302.7 & 3.2 & 58.8 & 304.5 & 53.9 & 5.5 & 4.7 \\
\hline D7 & 40.1 & -6.1 & 8 & 345.3 & 49.1 & 96.7 & 5.7 & 74.3 & 228.4 & 30.0 & 7.5 & 5.0 \\
\hline $\mathrm{CZ}$ & 40.1 & -5.8 & 11 & 343.8 & 41.7 & 632.7 & 1.8 & 68.9 & 219.3 & 24.0 & 2.2 & 1.3 \\
\hline $\mathrm{PT}$ & 40.2 & -5.7 & 10 & 329.2 & 53.6 & 78.9 & 5.5 & 64.9 & 260.2 & 34.1 & 7.7 & 5.3 \\
\hline D5-6 & 40.4 & -5.3 & 11 & 346.4 & 45.0 & 124.4 & 4.1 & 75.2 & 218.0 & 26.6 & 5.2 & 3.3 \\
\hline VT & 40.4 & -5.3 & 10 & 352.7 & 52.8 & 62.7 & 6.1 & 80.9 & 216.7 & 33.4 & 8.4 & 5.8 \\
\hline D3 & 40.6 & -4.6 & 3 & 344.3 & 56.0 & 179.5 & 9.2 & 77.1 & 252.2 & 36.5 & 13.2 & 9.5 \\
\hline D4 & 40.6 & -4.6 & 6 & 330.4 & 42.9 & 89.5 & 7.1 & 60.8 & 242.1 & 24.9 & 8.8 & 5.4 \\
\hline MU2 & 40.6 & -4.6 & 4 & 342.2 & 44.5 & 338.8 & 5.0 & 69.4 & 226.5 & 26.2 & 6.3 & 4.0 \\
\hline MU3 & 40.6 & -4.6 & 12 & 341.1 & 30.2 & 429.0 & 2.1 & 60.6 & 214.8 & 16.2 & 2.3 & 1.3 \\
\hline D1 & 40.7 & -4.5 & 5 & 333.5 & 38.6 & 285.7 & 4.5 & 60.7 & 233.3 & 21.8 & 5.3 & 3.2 \\
\hline D2 & 40.7 & -4.5 & 3 & 339.6 & 35.7 & 137.6 & 10.5 & 62.8 & 221.3 & 19.8 & 12.2 & 7.1 \\
\hline
\end{tabular}

SLat. and SLong. Site location in latitude and longitude; $n$. Number of specimens; Dec. and Inc. Declination and Inclination; $k$ and $\alpha_{95}$. Statistical parameters (Fisher, 1953); PLo. and PLa. Pole longitude and latitude; Palat. Paleolatitude; dm, dp. Semiaxes of the 95\% level confidence ellipse for the VGPs; *Rejected directions: see explanation in test; **Rejected VGPs: see explanation in text. 
Two or three pilot samples per site were thermally (Th) and alternating field (AF) demagnetized. The following steps were used for the thermal demagnetization of the pilot samples: steps of $50{ }^{\circ} \mathrm{C}$ from room temperature up to $475^{\circ} \mathrm{C}$ and then steps of $25^{\circ} \mathrm{C}$ up to $600-625{ }^{\circ} \mathrm{C}$. Susceptibility was monitored after each heating to control possible thermally induced mineralogical changes. For pilot AF studies, steps of $2.5 \mathrm{mT}$ (up to $20 \mathrm{mT}$ ), $5 \mathrm{mT}$ (between 20 and $45 \mathrm{mT}$ ) and then $55 \mathrm{mT}, 70 \mathrm{mT}, 85 \mathrm{mT}$ and $100 \mathrm{mT}$ were used.

The magnetic behaviour of pilot samples indicated that thermal demagnetization is more effective than $\mathrm{AF}$ in isolating the Characteristic Remanent Magnetization (ChRM). Therefore thermal demagnetization was systematically used with the remaining specimens with at least 10 temperature steps up to a maximum of $600{ }^{\circ} \mathrm{C}$. According to the magnetic behaviour during demagnetization, sites were divided into 4 groups:

- Group 1, 19 sites (AM, OD1, PO1, PO2, PO5, JU1$N$, JUI-R, JU2-N, JU2-R, GV1, CV1, CV2, D2, D5, $D 6, C Z, V T, M U 2$ and $M U 3)$. Specimens showed one stable magnetic component, after removal of a small viscous direction component. This magnetic component is isolated between $200-300{ }^{\circ} \mathrm{C}$ and $600{ }^{\circ} \mathrm{C}$ (maximum unblocking temperature) or between $10 \mathrm{mT}$ and $100 \mathrm{mT}$ (the maximum available field). This component exhibited normal polarity in 17 sites (Fig. 7a, b) but in two sites (JU1-R and JU2-R) showed reversed polarity (Fig. $7 \mathrm{c}, \mathrm{d}$ ).

- Group 2, 18 sites (MJ2, MS2, PO3, PO4, MB1, EL1, AL1, MN2, MN1, GR1, GR2, GR3, DV1, PL2, $P T, D 1, D 3$ and D4). Most specimens exhibited one stable magnetic component, but some (three to five specimens per site) exhibited two:(a)The low temperature/low coercitivity magnetic component was isolated between $100-200{ }^{\circ} \mathrm{C}$ and $400-450{ }^{\circ} \mathrm{C}$ or between 5-10 $\mathrm{mT}$ and $12-15 \mathrm{mT}$. This component presented, either, (i) the actual geomagnetic field direction (Fig. 7e) and is interpreted as a recently acquired secondary component; (ii) no common direction between different specimens of the same site (Fig. 7e, f). In this case the component is considered as a secondary one due to chemical alteration, hydrothermalism and/or IRMs acquired by lightning strikes (case of PT where specimens gave Qn ratios up of 10). (b) The high temperature component was isolated between $400-450{ }^{\circ} \mathrm{C}$ and $580-600{ }^{\circ} \mathrm{C}$ (maximum unblocking temperature) and was considered as the ChRM of the samples. This component exhibited normal polarity directions.
- Group 3, site MB2. Specimens exhibited three magnetic components (Fig. 8a): (a) A scattered viscous component (MB2-V: $n=12, \mathrm{Dec}=143.6, \mathrm{Inc}=30.4$, $\left.k=2.6, \alpha_{95}=34.1\right)$ was observed between room temperature up to $150{ }^{\circ} \mathrm{C}$. Direction of this component was calculated by Principal Component Analysis (PCA, Kirschvink, 1980) and it is plotted in Fig. 8d (diamonds). (b) A medium temperature magnetic component was observed between $100-200{ }^{\circ} \mathrm{C}$ and $400-450{ }^{\circ} \mathrm{C}$. This component exhibited a reversed polarity and was overlapped by the viscous component and by the high temperature component as well. Because of the overlapping, the mean direction of this component was calculated using the remagnetization circles method (Halls, 1976). The great circles considered were formed by the viscous (scattered) and the medium temperature magnetic components. In Fig. 8c great circles for all the specimens during thermal demagnetization processes are plotted, as well as the obtained mean direction (MB2-R). (c) A high temperature component was isolated between 400 $450{ }^{\circ} \mathrm{C}$ and $580-600{ }^{\circ} \mathrm{C}$ (maximum unblocking temperature) and was considered the ChRM of the samples. This component exhibited normal polarity directions (MB2-N in Fig. 8d). The reversed component direction (MB2-R, Table 1) is statistically indistinguishable of the mean reversed direction of JU1-R and JU2-R (star, Fig. 8d) and is interpreted as a thermal or

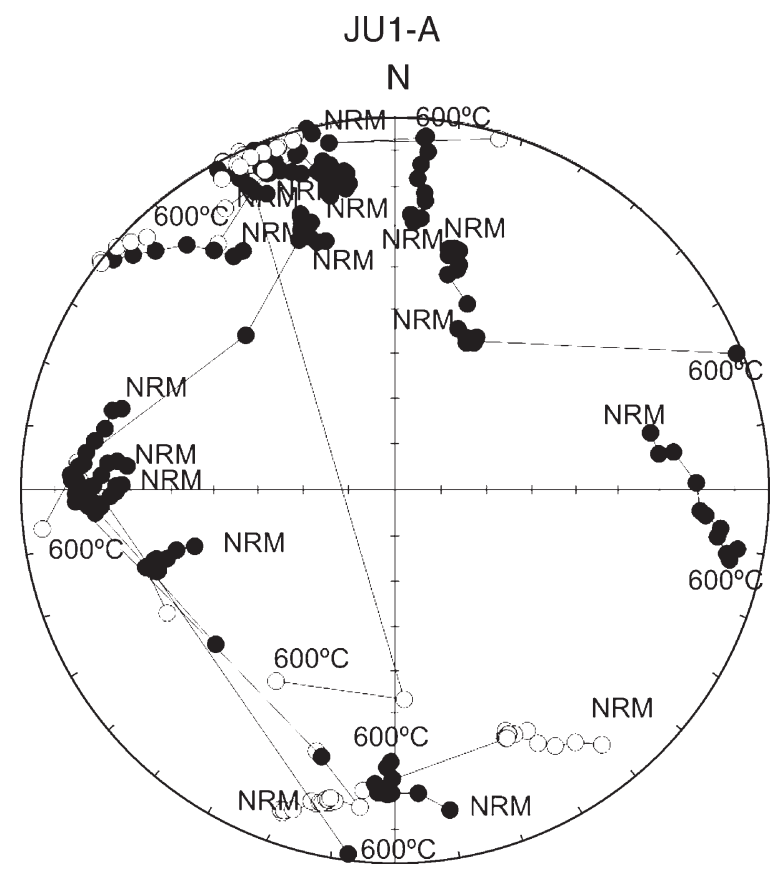

Fig. 9. Equal area of thermal demagnetization projections (site JU1-A). 
Table 2

Mean Pole value, Fisherian test, ChRM directions, reversal test results and statistical parameters

\begin{tabular}{lllllll}
\hline VGPs (sites) & $N$ & PLa & PLo & $K$ & A & Fish (PLa/PLo) \\
\hline VGPs (all sites) & 37 & 70.9 & 244.3 & 26.7 & 4.7 & No/No \\
VGP (excluding AL1 and PO1) & 35 & 70.4 & 237.6 & 47.9 & 3.5 & Yes/yes
\end{tabular}

\begin{tabular}{lrrrrrrr} 
ChRM directions (excluding AL1 and PO1) & \multicolumn{1}{c}{$N$} & Dec & Inc & $k$ & $\alpha_{95}$ & Rsum & Reversal test parameters \\
\hline Normal $(N)$ & 33 & 341.0 & 46.3 & 57.9 & 3.3 & 32.447 & $\gamma_{0}=17.72<\gamma_{\mathrm{c}}=36.89 ; R_{0}$ \\
Reversed $(R)$ & 2 & 136.8 & -55.3 & - & - & 1.988 & \\
Total $(N+R)$ & 35 & 339.9 & 46.9 & 52.1 & 3.4 & 34.346 & \\
\hline
\end{tabular}

$N$. Number of sites; PLa. Pole latitude; PLo. Pole longitude; Fish. Fisherian distribution in latitude and longitude; Dec. Declination; Inc. Inclination; $K, A_{95}, k, \alpha_{95}$, and Rsum. Statistical parameters (Fisher, 1953); $\gamma_{0}, \gamma_{c}$. Reversal test parameters (McFadden and McElhinny, 1990).

thermochemical overprint acquired during a reactivation of the dyke in a reversed geomagnetic field period. Site MB2 is in the proximity of Juromenha (JU1-R and JU2-R sites). Therefore, we interpreted that in this area the dyke had, at least, two intrusive events: (i) the main one occurred in a normal polarity geomagnetic period and (ii) the second intrusion emplaced in a reversed polarity geomagnetic time interval.

- Group 4, site JU1-A. Because of the presence of reversed polarities in JU1-R (small secondary dyke) and normal polarities in JU1-N (main dyke), a second field work was done. The aim of this sampling was to collect some rock specimens (JU1-A) at the contact of the main dyke with the small one.
Anomalous single directions or overlapped multicomponents behaviour have been observed (Fig. 9). This site exhibited a very complex behaviour, probably due to thermal/thermo-chemical alterations produced in the main dyke due to the secondary intrusion of JU1-R. In Fig. 9 is plotted the equal area demagnetization projections of JU1-A. Because of this complex magnetic behaviour, this site was rejected for next calculations.

\subsection{Paleomagnetic directions}

Characteristic remanent magnetization (ChRM) directions were computed by least squares fitting (Kirschvink, 1980) of the orthogonal demagnetization

\section{A}

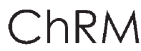

B
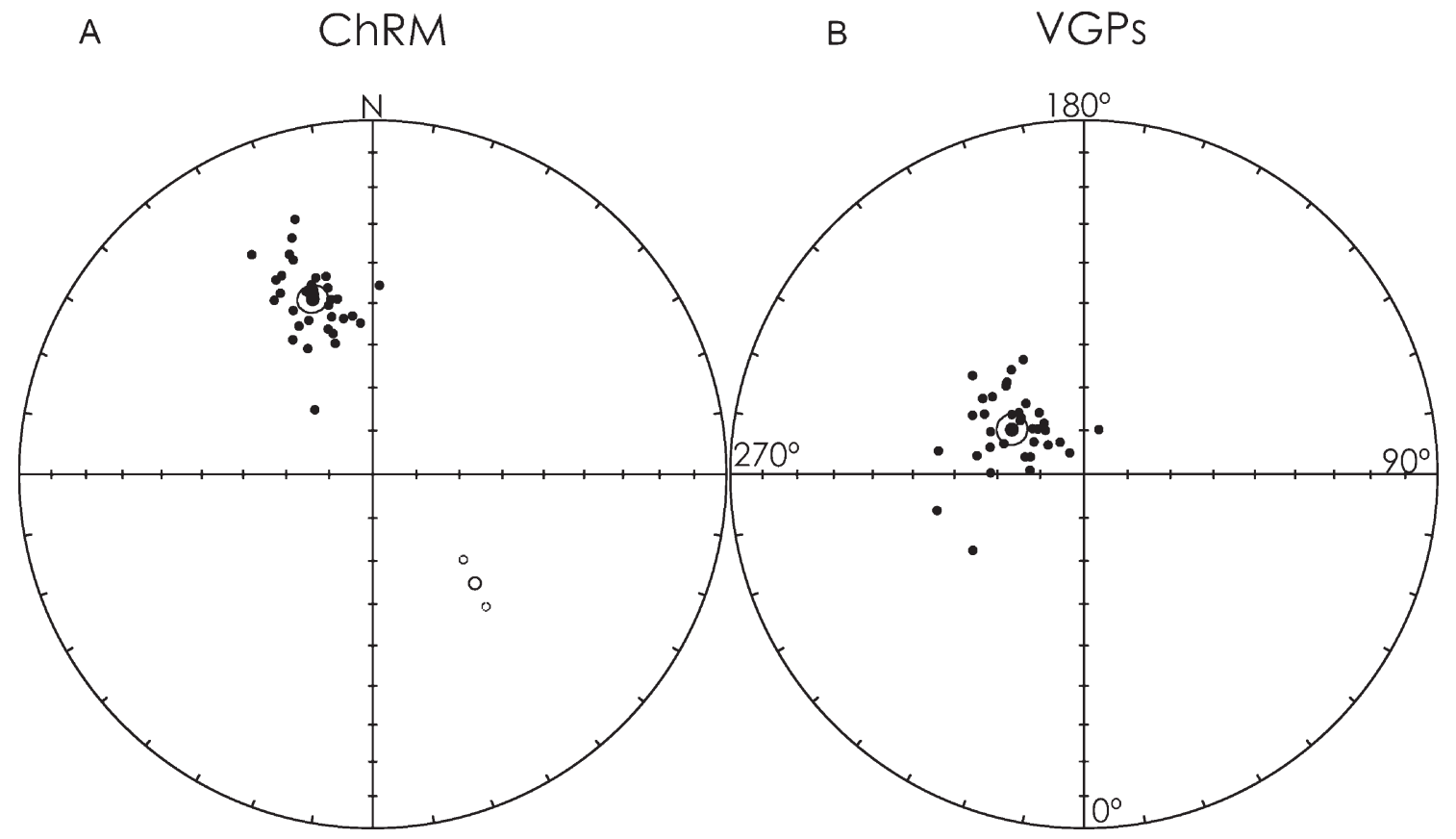

Fig. 10. Equal area projection of: (A) ChRM directions of the selected Messejana Plasencia sites, in filled symbols (normal polarities) open symbols (reversed polarities) and mean values with the $\alpha_{95}$ statistical parameters; and (B) VGPs directions of the selected Messejana Plasencia sites, mean value and the $A_{95 \%}$ statistical parameter. See values in Table 2 . 
plots. ChRM directions are well grouped in all investigated sites (see Table 1). We combined the sites D5 and D6 because of their proximity in the field and the low number of cores that were drilled (D5-6).

Cores from site MJ2 were drilled close to the border of the dyke outcrop in Murração (the southernmost site studied) and seem to present meteoric alterations when compared with the fresh samples from the central part of the dyke at the same site (called MS2 in order to distinguish it from the samples of the border). The ChRM mean direction of MJ2 is closed to the actual geomagnetic field, in contrast with the ChRM direction of MS2 (Table 1). We interpreted that samples located closest to the border presented an important weathering and their ChRM is dominated by a secondary component that was probably acquired recently by chemical processes. This site was rejected for the computation of the VGPs.

FOR each accepted site we calculated the VGPs (Table 1) and checked if the population of the 37 VGPs belonged to a Fisherian distribution (Table 2). The Fisherian test was negative when considering all sites, but positive excluding two sites, PO1 y AL1. There is field evidence indicating that AL1 has been affected by Tertiary and Quaternary deformation (Capote et al., 1996). PO1 is close to the border of the Mendro Chain, which is related to the so-called "Vidigueira fault", an inverse fault that crosses the dyke (Cabral and Ribeiro, 1988). These field evidences explains the negative Fisherian test result. On these bases, these two sites have been rejected.

The ChRM directions of the sites that belong to a Fisherian distribution pass the reversal test of McFadden and McElhinny (1990) with a positive indeterminate result $\left(R_{0}\right)$, see Table 2 and Fig. 10a. This result implies that we cannot refute the possibility of a common mean direction between the normal and reversed polarities.

ChRM and VGPs directions of the selected sites are shown in Fig. 10a, b. The mean value of the 35 remaining VGPs gives the definitive paleopole for the Messejana Plasencia dyke with values of: $N=35, \mathrm{PLa}=70.4\left({ }^{\circ} \mathrm{N}\right)$, $\mathrm{PLo}=237.6\left({ }^{\circ} \mathrm{E}\right), K=47.9$ and $A_{95}=3.5^{\circ}$.

\section{Discussion}

\subsection{On the primary/secondary origin of the ChRM}

The Messejana Plasencia paleopole derived from this study has been compared (see Fig. 11) with: those obtained by Schott et al. (1981), Perrin et al. (1991), the Cretaceous remagnetization $(N=11, \mathrm{PLo}=224.8, \mathrm{PLa}=$

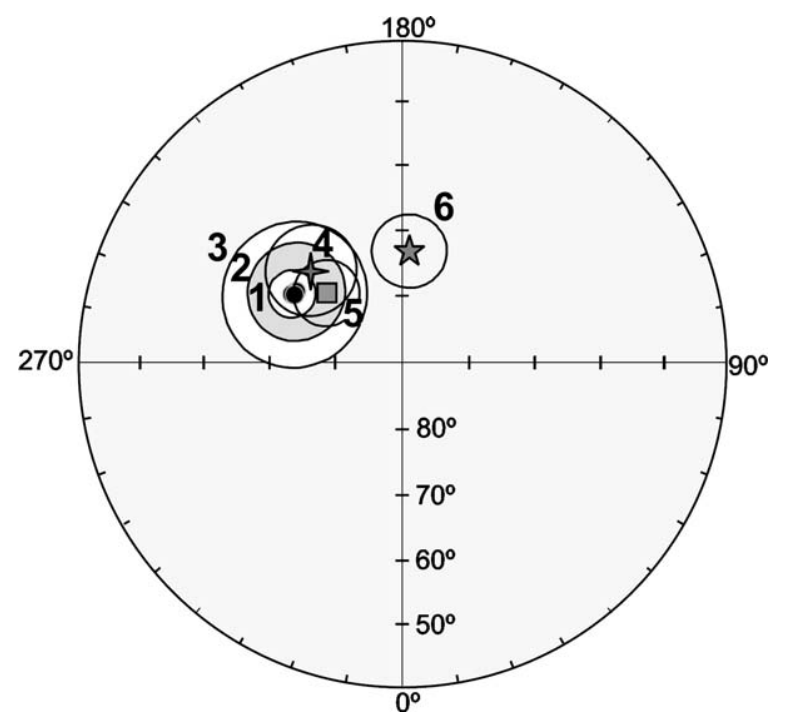

Fig. 11. Equal area projection of the paleopoles: (1) this study; (2) Schott et al. (1981); (3) Perrin et al. (1991); (4) the Cretaceous remagnetization of Juárez et al. (1998); (5) the mean Albian-Aptian paleopole of Iberia (Galdeano et al., 1989; Moreau et al., 1992, 1997); (6) the mean upper Cretaceous pole of Iberia (Van der Voo and Zijderveld, 1971; Van der Voo, 1969; Storetvedt et al., 1987, 1990) and the $\alpha_{95 \%}$ statistical parameters.

71.1, $\left.k=98.0, A_{95 \%}=6.8\right)$ of Juárez et al. (1998), the mean Albian-Aptian paleopole of Iberia $(N=3, \mathrm{PLo}=227.4$, $\mathrm{PLa}=74.5, k=615.0, A_{95 \%}=5.0$; Galdeano et al., 1989; Moreau et al., 1992, 1997) and the mean upper Cretaceous paleopole of Iberia $(N=5$, PLo $=176.3, \operatorname{PLa}=73.2$, $k=190.1, A_{95 \%}=5.6$; Van der Voo, 1969; Van der Voo and Zijderveld, 1971; Storetvedt et al., 1987, 1990).

The paleopole of the Messejana Plasencia dyke is indistinguishable from those obtained by Schott et al. (1981) and Perrin et al. (1991). It is also indistinguishable from the Cretaceous remagnetization of Juárez et al. (1998) and from the mean AlbianAptian pole, but distinguishable from the mean upper Cretaceous pole of Iberia.

If we assume a secondary origin for the ChRM, the age of the normal remagnetization should be AlbianAptian (according with the paleomagnetic poles) and the reversed magnetic components should be primary and acquired within the short reversed polarity chron M0 or M1 (considering the magnetic polarity time scale of Gradstein et al., 1994). Therefore, after the widespread event that could remagnetize the whole Iberia, a new reactivation of the dyke could took place coeval with the intrusion of the narrow secondary dykes and the partial remagnetization of the site MB2.

Magnetic properties of the remagnetized components observed in the Iberian Ranges, Pyrenees and Betics are 
common (Villalaín et al., 1994; Juárez et al., 1998; Dinarés-Turell and García-Senz, 2000): It is carried by magnetite of low unblocking temperature $\left(450^{\circ} \mathrm{C}\right)$. This behaviour has not been observed in the Dyke. In addition, magnetic properties of samples with normal (hypothetically remagnetized) and reversed polarities (primary origin) are very similar: Verwey transition well defined for both normal and reversed specimens; same unblocking temperatures and similar hysteresis parameters (Figs. 4, 5, 7).

The arguments given by Juárez et al. (1996), suggesting the remagnetization of the Messejana Plasencia dyke, were: (i) the absence of reversed polarities and (ii) the similitude of the Cretaceous and the Messejana Plasencia paleomagnetic directions.

The presence of reversed polarities in the two secondary dykes presented here allows us to reject the first of the arguments given by Juárez et al. (1996). In addition, the similitude in the magnetic properties of the normal and the reversed components point out to a common magnetization origin.

In relation with the second argument: If we transfer the African synthetic polar wander path of Besse and Courtillot (2002) to Iberia there is a loop in the curve in the Jurassic-Cretaceous segment. The expected middle Cretaceous and lower Jurassic poles are overlapped. Therefore the second argument given by Juárez et al. (1996) can be also been rejected. In our opinion it is more likely to consider that the dyke preserves its original magnetization than it is remagnetized. In the following discussion we will assume this hypothesis.

\subsection{The multiphase character of the dyke}

The existence of both polarities implies that the dyke had at least two intrusion events, separated in time by, at least, 10,000 y. In lower Jurassic times the maximum period of a normal chron is about $1 \mathrm{Ma}$ (Gradstein et al., 1994) and the reversal rate is very high. Within this context, and taking into account that most of the sites exhibited normal polarities, we consider that the main dyke intruded in a single and brief (less than $1 \mathrm{Ma}$ ) important event. Later, a second event, of very short magnitude and extension, took place characterized by narrow dykes with reversed magnetisation. This scenario seems more consistent with paleomagnetic data than multiphase intrusions (in which normal and reversed polarities would have the same probability). This is in agreement with other studies concluding that flood basalts appear to have been geologically instantaneous over much of the CAMP (McHone, 1996; Olsen et al., 1996; Olsen, 1997; Hames et al., 2000; Olsen et al., 2003). In addition, published paleomagnetic data from the CAMP are consistent with this study: the vast majority of the CAMP rocks exhibited normal polarity, but few reversal episodes were also observed (Knight et al., 2004).

\subsection{Block rotation in the Spanish Central System deformation}

In order to test the tectonic model Vegas et al. (1990), we compared the paleodeclinations of sites located in the northern branch of the dyke (that must be affected by

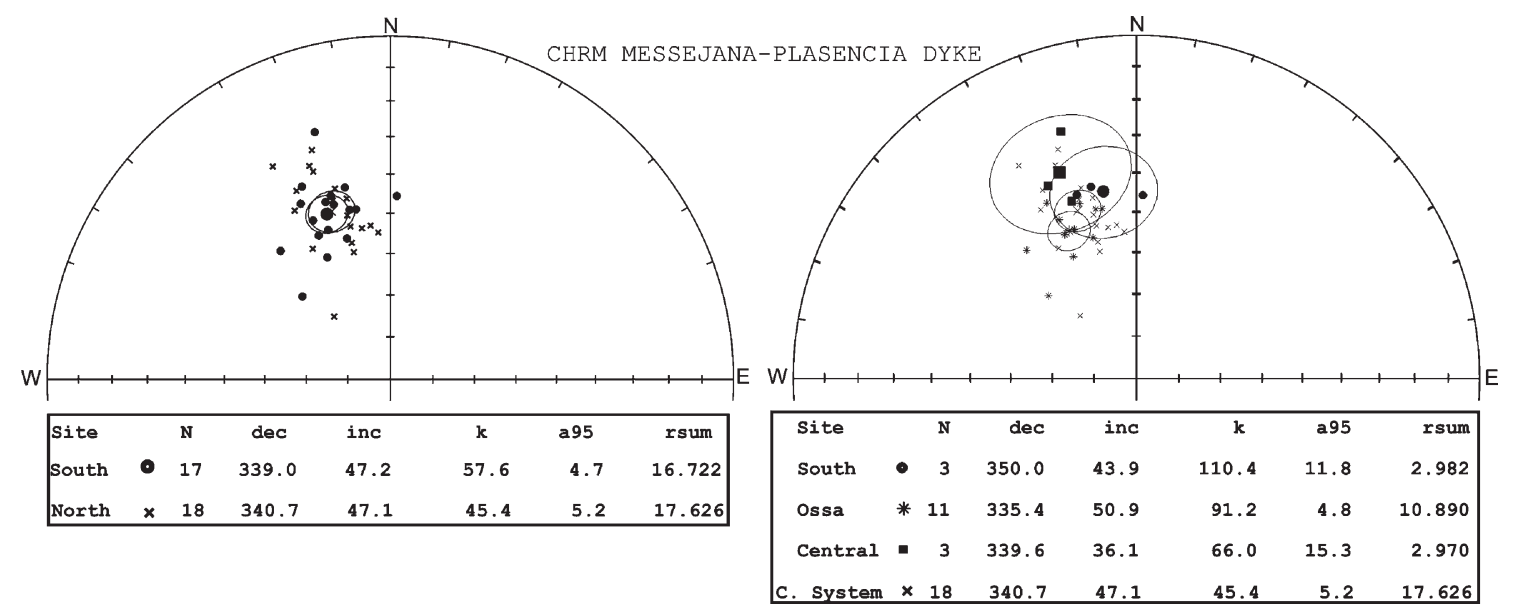

Fig. 12. Equal area projection of the ChRM directions of sites grouped in (a) the northern sites belong to the central Spanish System (dots) versus the 17 southern sites (crosses); and (b) sites grouped depending on the zones of Fig. 1: South Portuguese zone (dots), Ossa Morena zone (stars) and Central zone of the Variscan Iberian Massif: subdivided into Central Iberian zone (squares) and Spanish Central System zone (crosses). 
block rotations) with the paleodeclinations of sites located outside of the Spanish Central System. ChRM directions of the Messejana Plasencia sites were divided into two groups: (i) the 18 sites of the dyke located in the Spanish Central System (from CV1 to D2) and (ii) the 17 southern sites (from MS2 to GV1) (Fig. 12a). Comparing the ChRM directions of these two groups, we observe that there is no statistical difference between the respective means of each group. Trying to observe if the ChRM directions of the sites of the dyke are in some way affected by the different structural zones that cuts the dyke (Fig. 1), we also divided the population of ChRM directions of the Messejana Plasencia sites into four groups (Fig. 12b): (i) the 3 sites located in the Southern Portuguese zone (sites MS2, AM, OD), (ii) the 11 sites located in the Ossa Morena zone (sites PO2 to EL1); and the sites located in the Central Iberian zone that were subdivided into (iii) 3 sites located in the Central Iberian zone that is not affected by the Spanish Central System deformation (sites AL2, MN2, MN1) and finally (iv) the 18 sites of the dyke located in the Spanish Central System deformation (from CV1 to D2). There are no statistical differences in between the means ChRM directions of these groups, so there is no paleomagnetic evidence of block rotations affecting the dyke. Therefore the model proposed by Vegas et al. (1990) is not supported by the paleomagnetic data.

We derive from this comparison that the ChRM dyke directions are not affected by tectonics perturbations since its intrusion to the present day and this implies that the whole structure of the dyke remains in situ since lower Jurassic times.

Table 3

Selected paleomagnetic poles of lower Jurassic ages for Europe and North America from Besse and Courtillot (2002), and paleopoles rotated to Iberia

\begin{tabular}{|c|c|c|c|c|c|c|c|c|c|c|c|}
\hline $\begin{array}{l}\text { Place and rock name } \\
\text { (North America) }\end{array}$ & Age & Dage & PLa & PLo & $\mathrm{dm}$ & $\mathrm{dp}$ & SLat & SLong & $\begin{array}{l}\text { PLa rotated } \\
\text { to Iberia }\end{array}$ & $\begin{array}{l}\text { PLo rotated } \\
\text { to Iberia }\end{array}$ & Reference \\
\hline North Carolina, northwest dykes & 180 & 30 & 52.6 & 60.7 & 4.9 & 9.8 & 36 & -79.8 & 76.4 & 147.6 & Smith (1987) \\
\hline North Carolina, north-south dykes & 180 & 30 & 69.6 & 47.1 & 5.5 & 9.2 & 36 & -79.8 & 84.4 & 285.5 & Smith (1987) \\
\hline $\begin{array}{l}\text { Vermont (New Hampshire), } \\
\text { White mountain volcanics }\end{array}$ & 180 & 20 & 85.5 & 124.5 & 4.5 & 6 & 44 & -71 & 64.6 & 277.7 & $\begin{array}{l}\text { Opdyke and Wensink } \\
\text { (1966) }\end{array}$ \\
\hline $\begin{array}{l}\text { New Brunswick (Canada), } \\
\text { Caraquet dyke }\end{array}$ & 191 & 5 & 74.1 & 114 & 7.6 & 11.4 & 46.8 & -66 & 65.5 & 250.3 & Seguin et al. (1981) \\
\hline $\begin{array}{l}\text { Nova Scotia (Canada), } \\
\text { north mountain basalt }\end{array}$ & 191 & 10 & 73 & 104 & 4.5 & 6.5 & 44.9 & -65.4 & 68.2 & 246.4 & $\begin{array}{l}\text { Carmichael and } \\
\text { Palmer (1968) }\end{array}$ \\
\hline $\begin{array}{l}\text { South Carolina Piedmont, } \\
\text { diabase dykes }\end{array}$ & 194 & 8 & 66.1 & 96.1 & 4.9 & 9.3 & 34.3 & -81.5 & 69.5 & 226.1 & $\begin{array}{l}\text { Dooley and Smith } \\
\text { (1982) }\end{array}$ \\
\hline Combined Pennsylvania diabase & 195 & 10 & 62 & 104.5 & 1.5 & 1.5 & 40.2 & -76.3 & 64.5 & 220.3 & Beck (1972) \\
\hline Connecticut valley volcanics & 198 & 15 & 65.5 & 87.5 & 7.2 & 12.6 & 41.5 & -72.7 & 72.7 & 221.4 & De Boer (1968) \\
\hline Newark group & 200 & 20 & 63 & 108 & 3 & 4 & 40.5 & -75 & 63.6 & 224.2 & Opdyke (1961) \\
\hline Newark supergroup volcanics & 201 & 14 & 68 & 88.6 & 3.9 & 3.9 & 42 & -73 & 72.8 & 229.9 & $\begin{array}{l}\text { Prevot and McWilliams } \\
\text { (1989) }\end{array}$ \\
\hline $\begin{array}{l}\text { Pennsylvania, Culpeper Basin } \\
\text { intrusive and baked sediments }\end{array}$ & 201 & 14 & 65.5 & 73.1 & 3.7 & 3.7 & 39 & -77.5 & 78.6 & 217.4 & Kodama et al. (1994) \\
\hline $\begin{array}{l}\text { New Jersey, Newark Basin } \\
\text { Hettangian red beds }\end{array}$ & 206 & 5 & 5.5 & 94.5 & 5.4 & 5.4 & 40.5 & -74.3 & 65.0 & 200.9 & Witte and Kent (1990) \\
\hline $\begin{array}{l}\text { New Jersey, Passaic Formation, } \\
\text { Preakness basalts }\end{array}$ & 208 & 3 & 62.2 & 115.1 & 10.5 & 10.5 & 40.5 & -75 & 60.4 & 226.4 & Van Fossen et al. (1986) \\
\hline
\end{tabular}

\begin{tabular}{|c|c|c|c|c|c|c|c|c|c|c|c|}
\hline $\begin{array}{l}\text { Place and Rock Name } \\
\text { (Europe) }\end{array}$ & Age & Dage & PLa & PLo & $\mathrm{dm}$ & $\mathrm{dp}$ & SLat & SLong & $\begin{array}{l}\text { PLa rotated } \\
\text { to Iberia }\end{array}$ & $\begin{array}{l}\text { PLo rotated } \\
\text { to Iberia }\end{array}$ & Reference \\
\hline Sweden, Scanian basalts & 181 & 13 & 69 & 102 & 10 & 11 & 55.5 & 14 & 71.6 & 255.8 & $\begin{array}{l}\text { Bylund and Halvorsen } \\
\text { (1993) }\end{array}$ \\
\hline $\begin{array}{l}\text { France Thouars and Airvault } \\
\text { Toarcian stratotypes }\end{array}$ & 183 & 9 & 70.1 & 102.6 & 5.1 & 5.1 & 48 & -0.2 & 70.8 & 258.4 & Galbrun and Daly (1987) \\
\hline Yorkshire, U.K, Liassic sediments & 192 & 6 & 76.9 & 134.7 & 2.5 & 2.5 & 54.6 & -0.8 & 60.1 & 266.2 & Hijab and Tarling (1982) \\
\hline $\begin{array}{l}\text { Bretagne, France, } \\
\text { Kerforne dykes }\end{array}$ & 198 & 20 & 61.3 & 78.8 & 10.2 & 10.2 & 48.3 & -4.5 & 83.8 & 259.1 & Sichler and Perrin (1993) \\
\hline
\end{tabular}

Age. Mean age of magnetization, in Ma; Dage. Maximum age of magnetization minus minimum age; PLa. and PLo. Pole latitude and longitude; dp. and $\mathrm{dm}$. Semiaxes of the $95 \%$ level confidence ellipse for the VGP; SLat. and SLong. Site latitude and longitude. 
Table 4

Euler poles for rotation and finite angles used for this study

\begin{tabular}{llllll}
\hline Euler pole & $\begin{array}{l}\text { Age } \\
(\mathrm{Ma})\end{array}$ & $\begin{array}{l}\text { ELat } \\
\left({ }^{\circ} \mathrm{N}\right)\end{array}$ & $\begin{array}{l}\text { ELong } \\
\left({ }^{\circ} \mathrm{E}\right)\end{array}$ & $\begin{array}{l}\text { Rotation } \\
(\mathrm{deg})\end{array}$ & Reference \\
\hline $\begin{array}{c}\text { Iberia respect } \\
\text { to N. America }\end{array}$ & 175 & 65.7 & -12.8 & -66.3 & $\begin{array}{l}\text { Srivastava and } \\
\text { Verhoef (1992) }\end{array}$ \\
$\begin{array}{c}\text { Europe respect } \\
\text { to N. America }\end{array}$ & 175 & 71.6 & 156.7 & -25.3 & $\begin{array}{l}\text { Torsvik et al. } \\
(2001)\end{array}$ \\
\hline
\end{tabular}

\subsection{Comparison with lower Jurassic paleopoles of the North American and European plates}

The Messejana Plasencia paleopole is the only lower Jurassic paleopole for the Iberian Peninsula, so it is very important to be sure about its quality in order to develop the Apparent Polar Wander Path (APWP) for Iberia. Considering the reliability criteria of Van der Voo (1993), the pole obtained in this study passes 5 of the 7 criteria. The Messejana Plasencia paleopole derived from this study has been compared with the (rotated to the Iberian plate) selection of Jurassic paleopoles from the North American and European plates (see Table 3) made by Besse and Courtillot (2002). The good quality Jurassic paleopoles from
Table 5

Mean values of the selected paleomagnetic poles rotated to Iberia of Table 3 together with the paleopole of this study

\begin{tabular}{lrrllr}
\hline Mean values paleopoles & $N$ & PLa & PLo & $K$ & $\mathrm{~A}_{95 \%}$ \\
\hline Europe rotated to Iberia & 4 & 71.6 & 260.9 & 68.3 & 11.2 \\
North America rotated to Iberia & 13 & 71.8 & 229.2 & 47.6 & 6.1 \\
This study & 35 & 70.4 & 237.6 & 47.9 & 3.5 \\
\hline
\end{tabular}

$N$. Number of paleopoles or sites (in the case of this study); PLa. Pole latitude; PLo. Pole longitude; $K$ and $A_{95}$. Statistical parameters (Fisher, 1953).

North America and Europe have been rotated to Iberia using the Euler poles for rotation and finite angles listed in Table 4. As there are no direct Euler poles to rotate Europe in to Iberia, the European paleopoles were first rotated to North America and subsequently to Iberia.

In Fig. 13 the North American and European Jurassic paleopoles rotated to Iberia are plotted, along with their mean values with the respective $A_{95 \%}$ statistical parameter, plus the Messejana Plasencia paleopole derived from the present study (Table 5). All poles are statistically indistinguishable. It means that the Euler Poles for rotation and finite angles used

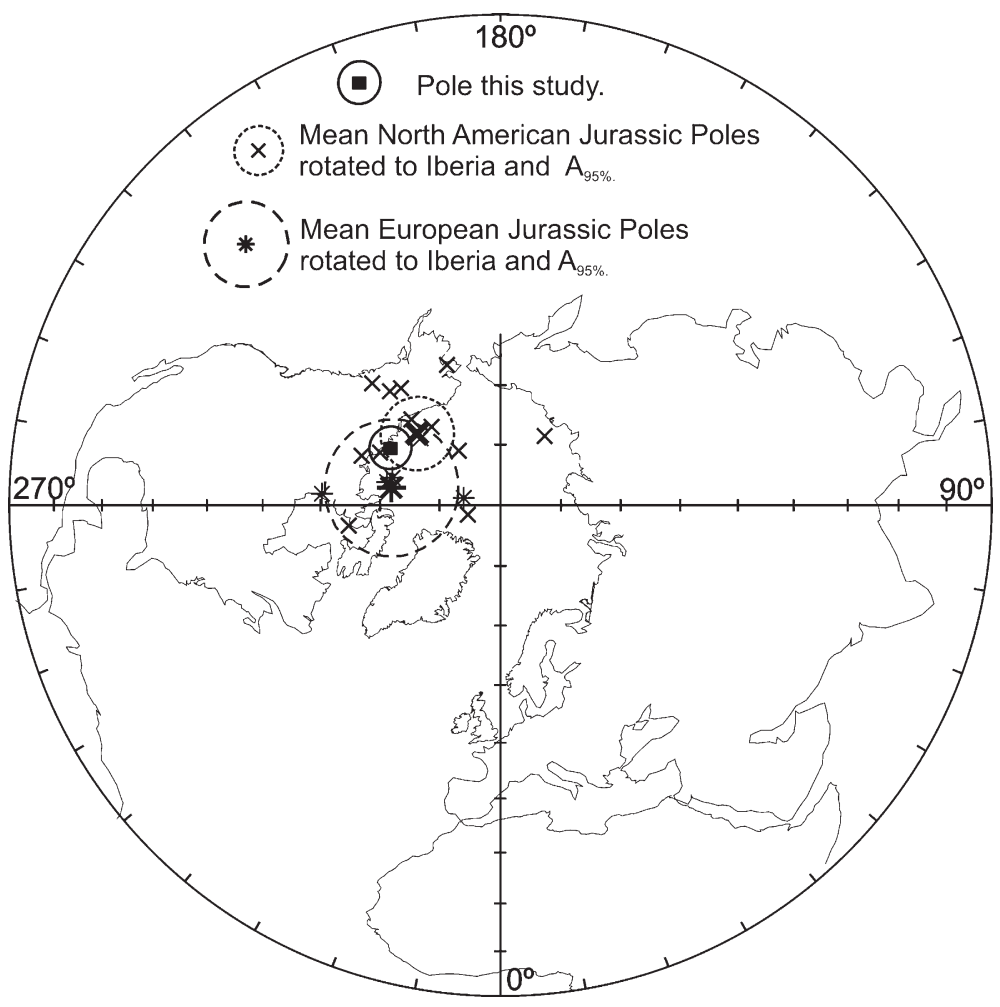

Fig. 13. Equal area projection of the selected North American and European Jurassic paleopoles rotated to Iberia, their mean values with the $A_{95 \%}$ statistical parameters, and the Messejana Plasencia paleopole. 
for this comparison are consistent with paleomagnetic data.

\section{Conclusions}

In conclusion, our paleomagnetic study of the Messejana Plasencia dyke showed that magnetite and/ or low Ti-titanomagnetite are the minerals carrying the magnetization. The ChRM directions of the studied sites are mostly of normal polarity, with the exception of two sites in the Juromenha zone (Portuguese part) where reversed polarities ChRM directions are observed. The two polarities average ChRM directions are indistinguishable.

Considering the magnetic properties of the normal and reversed directions, the available Cretaceous poles for Iberia and the African poles, we concluded that the magnetization of the dykes is of primary origin.

The intrusion of the dyke appears to have been geologically instantaneous. But, the dyke had at least two intrusion events, separated in time by at least $10,000 \mathrm{y}$. The main intrusion took place during a period of normal polarity of the geomagnetic field. The second event was of less magnitude, restricted to a small region (Juromenha area, Portugal) and took place during a reversed polarity period of the field. The intrusion of the Messejana Plasencia dyke presents similar characteristics to the observed in much of the Central Atlantic Magmatic Province.

There is no important tectonic activity in the dyke affecting the paleomagnetic directions and structure of the dyke. The existence of a rotational deformation within the Spanish Central System is not evidenced by paleomagnetic data.

The Paleomagnetic Pole derived from the average of the VGPs is well defined, with values of: $N=35$, $\mathrm{PLa}=70.4^{\circ} \mathrm{N}, \mathrm{PLo}=237.6^{\circ} \mathrm{E}, K=47.9$ and $A_{95}=3.5^{\circ}$ and it is a good quality lower Jurassic paleopole for the Iberian plate.

The paleomagnetic pole from the Messejana Plasencia dyke is in agreement with the selection of Jurassic paleopoles from North America and Europe made by Besse and Courtillot (2002) when rotated to Iberia with the available Euler poles of Srivastava and Verhoef (1992) and Torsvik et al. (2001). This evidences the internal consistency between these paleomagnetic and magnetic anomalies data sets.

\section{Acknowledgements}

The authors appreciate very much the help of so many people involved in this project: Vicente Carlos
Ruiz-Martínez, Gregg McIntosh and Miriam Gomez, Miguel Miranda and Paulo Fonseca during field-work; Juanjo Villalaín, Victor Villasante, Mónica Maceira for their work in some of the studied sites. We are grateful to Vicente Carlos Ruiz-Martínez for enriching discussion during revision of this paper. Criticism and suggestions of the reviewers, R. Van der Voo and B. Henry, help us to improve this paper. This work has been supported by the Dirección General de Investigación Científica y Tecnológica DGICYT (projects BTE2002-00854 and GCL2005-00211/BTE).

\section{References}

Beck, M.E., 1972. Paleomagnetism of upper Triassic diabase from southeastern Pennsylvania: further results. Journal Geophysical Research 77, 5673-5687.

Besse, J., Courtillot, V., 2002. Apparent and true polar wander and the geometry of the magnetic field in the last 200 million years. Journal Geophysical Research 107, 6-1-6-31.

Burov, B., Nurgaliev, D.K., Jasonov, P.G., 1986. Paleomagnetic Analysis. Kazan University Press. 176 pp. (in Russian).

Bylund, G., Halvorsen, E., 1993. Palaeomagnetic study of Mesozoic basalts from Scania, southernmost Sweden. Geophysical Journal International 114, 138-144.

Cabral, J., Ribeiro, A., 1988. Carta Neotectónica de Portugal Continental, escala 1:1.000.000. Departamento de Geologia da Faculdade de Ciências de Lisboa, Serviços Geológicos de Portugal, Gabinete de Protecção e Segurança Nuclear, editada pelos SGP.

Carmichael, C.M., Palmer, C.H., 1968. Paleomagnetism of the late Triassic North Mountain Basalt of Nova Scotia. Journal Geophysical Research 73, 2811-2822.

Carvalhosa de Barros, A., 1965. Contribuçao para o conhecimento geologico da regiao entre Portel e Ficalho (Alentejo). Ser. Geol. Portugal, Mem., vol. 11. 132 pp.

Capote, R., Villamor, P., Tsige, M., 1996. La tectónica alpina de la Falla de Alentejo-Plasencia (Macizo Hespérico). Geogaceta 20, 921-924.

Day, R., Fuller, M.D., Schmidt, V.A., 1977. Hysteresis properties of titanomagnetites: grain size and composition dependence. Physics of the Earth and Planetary Interiors 13, 260-266.

De Boer, J., 1968. Paleomagnetic differentiation and correlation of the late Triassic volcanic rocks in the central Appalachians (with special reference to the Connecticut Valley). Geological Society American Bulletin 79, 609-626.

De Bruijne, C.H. (2001). Denudation, intraplate tectonics and far field effects. An integrated apatite fission track study in central Spain. Published Ph-D Thesis, Vvrije Universiteit Amsterdam, the Netherlands.

De Vicente, G., 2004. Estructura alpina del Antepaís Ibérico. In: Vera, J.A. (Ed.), Geología de España, Sociedad Geológica de EspañaInstituto Geológico y Minero de España, pp. 587-635.

Del Valle Lersundi, J., 1959. Sobre la posible existencia de una importante falla en el SO de la Península. Noticiario de la Comision Instituto Geológico Minero España 56, 103-108.

Dinarés-Turell, J., García-Senz, J., 2000. Remagnetization of lower Cretaceous limestones from the southern Pyrenees and relation to the Iberian plate geodynamic evolution. Journal Geophysics Research 105, 19,405-19,418. 
Dooley, R.E., Smith, W.A., 1982. Age and magnetism of diabase dykes and tilting of the Piedmont. Tectonophysics 90, 283-307.

Dunlop, D.J., 2002a. Theory and application of the Day plot (Mrs/Ms versus $\mathrm{Hcr} / \mathrm{Hc}$ ): 1. Theoretical curves and tests using titanomagnetite data. Journal of Geophysical Research 107, 4.1-4.22.

Dunlop, D.J., Schutts, L.D., Hale, C.J., 1984. Paleomagnetism of Archean rocks from northwestern Ontario: III. Rock magnetism of the Shelley Lake granite, Quetico Subprovince. Canadian Journal Earth Sciences 21, 879-886.

Dunn, A.M., Reynolds, P.H., Clarke, D.B., Ugidos, J.M., 1998. A comparison of the age and composition of the Shelburne dyke, Nova Scotia, and the Messejana dyke, Spain. Canadian Journal of Earth Sciences 35, 1110-1115.

Feio, M., 1951. A evolussao do relevo do Baixo Alentejo e Algarve. Com. Serv. Geol. Portugal, vol. 32, pp. 303-477.

Fisher, R.A., 1953. Dispersion on a sphere. Proceedings of the Royal Society, London, A. 217, 295-305.

Galbrun, B., Daly, L., 1987. Etablissement d'une pole paleomagnetique pour la plate-forme européenne stable a l'époque toarcienne. Comptes Rendus de l'Academie des Sciences. Paris Series II 305, 773-776.

Galdeano, A., Moreau, M.G., Pozzi, J.P., Berthou, P.Y., Malod, J.A., 1989. New paleomagnetic results from Cretaceous sediments near Lisboa (Portugal) and implications for the rotation of Iberia. Earth and Planetary Science Letters 92, 95-106.

García de Figuerola, L.C., 1963. El dique diabásico del Norte de Extremadura. Noticiario de la Comision Instituto Geológico Minero España 69, 43-78.

García de Figuerola, L.C., 1965. La continuación hacia el SW del dique básico de Plasencia (Cáceres). Noticiario de la Comision Instituto Geológico Minero España 77, 129-164.

García de Figuerola, L.C., Carnicero, A., 1973. El extremo noreste del gran dique de Alentejo-Plasencia. Studia Geologica (Salamanca) $6,73-84$.

García de Figuerola, L.C., Corretgé, L.G., Bea, F., 1974. El dique de Alentejo-Plasencia y haces de diques básicos de Extremadura. Boletin Geologico Minero (Madrid) 85, 308-337.

Gradstein, F.M., Agterberg, F.P., Ogg, J.G., Handerbol, J., Van Veen, P., Thierry, J., Huang, Z., 1994. A Mesozoic time scale. Journal Geophysical Research 99, 24.051-24.074.

Halls, H.C., 1976. A least-squares method to find a remanence direction from a converging remagnetization circles. Geophysical Journal Royal Astronomy Society 45, 279-304.

Hames, W., Renne, E., Ruppel, R., 2000. New evidence for geologically instantaneous emplacement of earliest Jurassic Central Atlantic magmatic province basalts on the North American margin. Geology 28, 859-862.

Hijab, B.R., Tarling, D.H., 1982. Lower Jurassic palaeomagnetic results from Yorkshire, England, and their implications. Earth and Planetary Science Letters 60, 147-154.

Juárez, M.T., Osete, M.L., Meléndez, G., Langereis, C.G., Zijderveld, J.D.A., 1994. Oxfordian magnetostratrigraphy of the Aguilón and Tosos sections (Iberian Range Spain) and evidence of a preOligocene overprint. Physics of the Earth and Planetary Interiors $85,195-211$.

Juárez, M.T., Osete, M.L., Meléndez, G., Lowrie, W., 1995. Oxfordian magnetostratigraphy in the Iberian Range. Geophysical Research Letters 22, 2889-2892.

Juárez, M.T., Osete, M.L., Vegas, R., Langereis, C.G., Meléndez, G., 1996. Paleomagnetic study of Jurassic limestones from the Iberian Range (Spain): tectonic implications. In: Morris, A., Tarling, D.H.
(Eds.), Paleomagnetism and Tectonic of the Mediterranean Region. Geological Society London, vol. 8396.

Juárez, M.T., Lowrie, W., Osete, M.L., Melendez, G., 1998. Evidence of widespread Cretaceous remagnetization in the Iberian Range and its relation with the rotation of Iberia. Earth and Planetary Science Letters 160, 729-743.

Knight, K.B., Nomade, S., Renne, P.R, Marzoli, A., Bertrand, H., Youbie, N., 2004. The Central Atlantic Magmatic Province at the Triassic-Jurassic boundary: paleomagnetic and 40Ar/39Ar evidence from Morocco for brief, episodic volcanism. Earth and Planetary Science Letters 228, 143-160.

Kirschvink, J.L., 1980. The least-square line and plane and the analysis of paleomagnetic data. Geophysical Journal Royal Astronomy Society 62, 699-718.

Kodama, K.P., Cioppa, M.T., Sherwood, E., Warnock, A.C., 1994. Paleomagnetism of baked sedimentary rocks in the Newark and Culpeper basins: evidence for the J1 cusp and significant late Triassic apparent polar wander from the Mesozoic basins of North America. Tectonics 13, 917-928.

Lowrie, W., 1990. Identification of ferromagnetic minerals in a rock by coercivity and unblocking temperature properties. Geophysical Research Letters 17, 159-162.

Marzoli, A., Renne, P.R., Piccirillo, E.M., Ernesto, M., Bellieni, G., De Min, A., 1999. Extensive 200 million-year-old continental flood basalt s of the Central Atlantic Magmatic Province. Science 284, 616-618.

McFadden, P.L., McElhinny, M.W., 1990. Classification of the reversal test in paleomagnetism. Geophysical Journal International 103, 725-729.

McHone, J.G., 1996. Broad-terrane Jurassic flood basalts across northeastern North America. Geology 24, 319-322.

Moreau, M.G., Canerot, J., Malod, J.A., 1992. Paleomagnetic study of Mesozoic sediments from the Iberian Chain (Spain). Suggestions for Barremian remagnetization and implications for the rotation of Iberia. Bulletin de la Societe Geologique de France 163 (4), 393402.

Moreau, M.G., Berthou, J.Y., Malod, J.A., 1997. New paleomagnetic Mesozoic data from the Algarve (Portugal): fast rotation of Iberia between the Hauterivian and the Aptian. Earth Planetary Science Letters 146, 689701.

Olsen, P.E., 1997. Stratigraphic record of the early Mesozoic breakup of Pangea in the Laurasia-Gondwana rift system. Annual Reviews of Earth and Planetary Science 25, 337-401.

Olsen, P.E., Schlische, R.W., Fedosh, M.S., 1996. 580 ky duration of the early Jurassic flood basalt event in eastern North America estimated using Milankovitch cyclostratigraphy. Bulletin du Musee North Arizona 60, 11-22.

Olsen, P.E., Kent, D.V., Et-Touhami, M., Puffer, J.H., 2003. Cyclo-, magneto-, and bio-stratigraphic constraints on the duration of the CAMP event and its relationship to the Triassic-Jurassic boundary. In: Hames, W.E., McHone, J.G., Renne, P.R, Ruppel, C. (Eds.), The Central Atlantic Magmatic Province: Insights From Fragments of Pangea. Geophysical Monograph Series, vol. 136, pp. 7-32.

Opdyke, N.D., 1961. The paleomagnetism of the New Jersey Triassic: a field study of the inclination error in red sediments. Journal Geophysical Research 66, 1941-1949.

Opdyke, N.D., Wensink, H., 1966. Paleomagnetism of rocks from the White Mountain Plutonic Volcanic Series in New Hampshire and Vermont. Journal Geophysical Research 71, 3045-3051.

Parga, J.R., 1969. Spätvariszische Bruchsusteme im Hesperischen Massiv. Geologische Rundschau 59, 323-336. 
Perrin, M., Prevot, M., Mankinen, E.A., 1991. Low intensity of the geomagnetic field in early Jurassic time. Journal of Geophysical Research 96 (9), 14-197-14-210.

Prevot, M., McWilliams, M., 1989. Paleomagnetic correlation of Newark Supergroup volcanics. Geology 17, 1007-1010.

Quesada García, A., 1960. Falla de desgarre en el SW de la Península Ibérica. Noticiario de la Comision Instituto Geológico Minero España 58, 163-182.

Rapaille, C., Marzoli, A., Bertrand, H., Féraud, G., Reisberg, L., Fontignie, D., 2003. Geochemistry and $40 \mathrm{Ar} / \mathrm{Ar}$ age of the European part of the Central Atlantic Magmatic Province. Geophysical Research Abstracts 5, 11791.

Rincón, P.J., Hermosilla, J., Vegas, R., Pascual, G., Muñoz-Martín, A., Martínez-Solares, J.M., 2000. Cálculo automático del desplazamiento en un sector del sistema falla-dique de Plasencia, pp. $143-146$.

Seguin, M.K., Rao, K.V., Venugopal, D.V., Gahe, E., 1981. Paleomagnetism of parts of the late Triassic diabase dike system associated with the trans-New Brunswick aeromagnetic lineament. Canadian Journal Earth Sciences 18, 1776-1787.

Schermerhorn, L.J.G., Priem, H.N.A., Boelrijk, N.A., Hebeda, E.H., Verdumen, E.A. Th., Verschure, R.H., 1978. Age and origin of the Messejana dolerite fault-dyke system (Portugal and Spain) in the light of the opening of the North Atlantic Ocean. Journal of Geology 86, 299-309.

Schott, J.J., Montigny, R., Thuizat, R., 1981. Paleomagnetism and potassium-argon age of the Messejana dyke (Portugal and Spain): angular limitation to the rotation of the Iberian Peninsula since the middle Jurassic. Earth and Planetary Science Letters 53, 457-470.

Sebai, A., Feraud, G., Bertrand, H., Hanes, J., 1991. ${ }^{40} \mathrm{Ar} /{ }^{39} \mathrm{Ar}$ dating and geochemistry of tholeitic magmatism related to the early opening of the central Atlantic rift. Earth and Planetary Science Letters 104, 455-472.

Sichler, B., Perrin, M., 1993. New early Jurassic paleopole from France and Jurassic apparent polar wander. Earth and Planetary Science Letters 115, 13-27.

Smith, W.A., 1987. Paleomagnetic results from a crosscutting system of northwest and north-south trending diabase dikes in the North Carolina Piedmont. Tectonophysics 136, 137-150.

Srivastava, S.P., Verhoef, J., 1992. Evolution of Mesozoic sedimentary basins around the North Central Atlantic: a preliminary plate kinematic solution. In: Parnell, J. (Ed.), Basins on the Atlantic seaboard: Petroleum Geology, Sedimentology and Basin Evolution. Geological Society, London, pp. 397-420. Special Publication.

Stacey, F.D., 1967. The Koenigsberger ratio and the nature of thermoremanence in igneous rocks. Earth and Planetary Science Letters 2, 67-68.

Steiner, M.B., Ogg, J.G., Melendez, G., Sequeiros, L., 1985. Jurassic magnetostratigraphy: 2. Middle-late Oxfordian of Aguilon, Iberian Cordillera, northern Spain. Earth and Planetary Science Letters 76, 151-166.

Storetvedt, K.M., Mogsta, H., Abranches, M.C., Mitchell, J.G., Serralheiro, A., 1987. Paleomagnetism and isotopic age data from upper Cretaceous igneous rocks of W. Portugal; geological correlation and plate tectonic aspects. Geophysical Journal Royal Astronomy Society 88, 241-263.
Storetvedt, K.M., Mitchell, J.G., Abranches, M.C., Oftedahl, S., 1990 A new kinematic model for Iberia; further palaeomagnetic results and isotopic age evidence. Physics of the Earth and Planetary Interiors 62, 109-125.

Torre de Assunção, 1949. Sobre uma intrusao doleritica no Antracolitico do Baixo-Alentejo. Boletim da Sociedade Portuguesa de Ciencias Naturais Series 2 (17), 66-74.

Torre de Assunção, 1951a. Os dorelitos pigconiticos de quimismo pacifico do Sul de Portugal. Boletim da Sociedade Portuguesa de Ciencias University Lisboa Series 6 (19), 109-117.

Torre de Assunção, 1951b. Dorelitos da regiao de Aljustrel. Boletim do Museu e Laboratorio Mineralogico e Geologico da Faculdade de Ciencias, Universidade de Lisboa Series 6 (19), 119-122.

Torsvik, T.H., Van der Voo, R., Meert, J.G., Mosa, J., Walderhaug, H.J., 2001. Reconstructions of the continents around the North Atlantic at about the 60th parallel. Earth and Planetary Science Letters 187, $55-69$.

Van der Voo, R., 1969. Paleomagnetic evidence for the rotation of the Iberian Península. Tectonophysics 7, 5-56.

Van der Voo, R., 1993. Paleomagnetism of the Atlantic, Tethys, and Iapetus Ocean. Cambridge University Press.

Van der Voo, R., Zijderveld, J.D.A., 1971. Renewed paleomagnetic study of the Lisbon Volcanics and implications for the rotation of the Iberian Peninsula. Journal of Geophysical Research 76, 3913-3921.

Van Fossen, M.C., Flynn, J.J., Forsythe, R.D., 1986. Paleomagnetism of early Jurassic rocks, Watchung Mountains, Newark Basin: evidence for complex rotations along the Border fault. Geophysical Research Letters 13, 185-188.

Vegas, R., 2000. The intrusion of the Plasencia (Messejana) dyke as part of the Circum-Atlantic early Jurassic magmatism: tectonic implications in the southwester Iberian Peninsula. Geogaceta 175-178.

Vegas, R., Vázquez, J.T., Suriñach, E., Marcos, A., 1990. Model of distributed deformation, block rotations and crustal thickening for the formation of the Spanish Central System. Tectonophysics 184 (3-4), 367-378.

Verwey, E.J.W., Haayman, P.W., 1941. Electronic conductivity and transition point in magnetite. Physica 8, 979-982.

Villalaín, J.J., Osete, M.L., Vegas, R., García Dueñas, V., Heller, F., 1994. Widespread Neogene remagnetization in Jurassic limestones of the South-Iberian paleomargin (Western Betics, Gibraltar Arc). Physics of the Earth and Planetary Interior 85, 15-33.

Villalaín, J.J., Osete, M.L., Vegas, R., García Dueñas, V., Heller, F., 1996. The Neogene remagnetization in the western Betics: a brief comment on the reliability of paleomagnetic directions. In: Morris, A., Tarling, D.H. (Eds.), Paleomagnetism and Tectonics of the Mediterranean Region. Geological Society Special Publication, vol. 105 , pp. 33-41.

Witte, W.K., Kent, D.V., 1990. The paleomagnetism of red beds and basalts of the Hettangian Extrusive Zone, Newark Basin, New Jersey. Journal Geophysical Research 95, 17533-17545.

Zbyszewski, G., Freire de Andrade, R., 1957. Nota preliminar sobre la geología da regiao de Aljustrel: Assoc. Portuguesa Progresso Cienc: 23. Congr. Luso-Español, V.5, sec. 4, Coimbra. 1956, pp. $5-13$. 